\title{
Independent Distributors in Servitization: An Assessment of Key Internal and Ecosystem-related Problems
}

\author{
Dusana Hullova ${ }^{1,4}$, Pavel Laczko², Johan Frishammar ${ }^{3}$ \\ ${ }^{1}$ University of Portsmouth, Faculty of Business and Law, Richmond Building, Portland Street, Portsmouth PO13 \\ DE, UK, $t:+44(0) 2392844093$ \\ ${ }^{2}$ University of Portsmouth, Faculty of Business and Law, Richmond Building, Portland Street, Portsmouth PO13 \\ $D E, U K, t:+44$ (0) 7863473074 \\ ${ }^{3}$ Entrepreneurship and Innovation Research Group, Luleå University of Technology, SE-97187 Luleå, Sweden, \\ $t:+46(0) 920491407$ \\ ${ }^{4}$ University of Roehampton London, Roehampton Business School, Roehampton Lane, London, SW155PJ, UK, \\ t:+44 (0)2083927260 (Corresponding author)
}

\begin{abstract}
Independent distributors (IDs), just as equipment manufacturers, have the potential to initiate a transition towards the provision of advanced services. However, the internal and ecosystemrelated problems experienced by IDs during servitization differ due to their distinct organizational structure. The purpose of this study is therefore to uncover problems faced by servitizing IDs during transition towards provision of advanced services, a topic which is still scarcely covered in the literature. Using an abductive research approach, we identify three overarching groups of servitization problems specific to IDs: (1) Conflicting interests of key stakeholders; (2) Misalignment between distribution of managerial attention and servitization strategy; and (3) Ineffective knowledge management within the ecosystem. To diagnose these problems, we propose a servitization-readiness decision tree that allows IDs to pinpoint hindering factors before embarking on a servitization journey. In so doing, we provide a starting point for identifying and describing criteria for assessing IDs' servitization readiness.
\end{abstract}

Keywords: Servitization readiness, Independent distributor, Servitization problems, Servitization ecosystem, Product service system, Manufacturing industry 


\section{Independent Distributors in Servitization: An Assessment of Key Internal and Ecosystem-related Problems}

\section{Introduction}

In servitization, equipment manufacturers rely on direct and indirect distribution channels to extend their market reach (Hakanen, Helander \& Valkokari, 2017; Olsson, Gadde \& Hulthén, 2013). As the needs of business customers are becoming increasingly more complex, higher pressure is being put on distribution actors to integrate products with advanced services into customized solutions (Gebauer \& Fleisch, 2007; Hakanen et al., 2017; Parida, Rönnberg Sjödin, Wincent \& Kohtamäki, 2014). Manufacturers often respond to these challenges by designing advanced service solutions and delivering those themselves, through their own dealers, and independent distributors (IDs). Given the proximity of IDs to business customers, they are usually the first to identify customers' changing needs. IDs not only serve a broader range of customers, but also work with multiple manufacturers, which in comparison to manufacturer-owned dealers allows them to gain more profound insights into new trends, customer needs, emerging technology, and production processes. Manufacturers rely on these insights to not only guide their new product development but ultimately their servitization initiatives. Despite their central position within the network, the role of IDs in servitization is overlooked, at best marginalized, and often assumed to be identical to the role that manufacturer-owned dealers play. This assumption is impeding our understanding of the potential and the part that IDs play in supporting and initiating servitization. Just as the equipment manufacturers, IDs can be strong drivers in the transition to servitization and become 'proactive channel partners' (Kowalkowski \& Ulaga, 2017, p. 231). However, the prerequisites and conditions under which the IDs can lead such transition remain scant in the nascent literature. In particular, their role as an intermediary between the customer and the 
equipment manufacturer places IDs in an ideal position to initiate and lead servitization. In an ecosystem, where the equipment manufacturer operates through one or more IDs, the manufacturer is contingent upon ID’s ability to deliver and install its equipment. Additionally, IDs often train customers' operators, schedule repairs, provide spare parts throughout the lifecycle of equipment as well as gather and share customer insights. Customer knowledge and ‘closeness’ may, therefore, be the ID’s key asset (Frazier et al., 2009; Li, Liu \& Liu, 2011).

However, the literature does not fully take into account such scenarios and continues to focus mainly on the capabilities and challenges of equipment manufacturers (Oliva \& Kallenberg, 2003; Ulaga \& Loveland, 2014; Ulaga \& Reinartz, 2011). Studies have regarded IDs as servicecentric 'by nature', responsible not only for sales but also for marketing and for building and nurturing customer relationships (Story et al., 2017). Nevertheless, IDs, like equipment manufacturers, can face many challenges during the transition from a product-centric to a service-centric logic (Benedettini, Neely \& Swink, 2015; Ulaga \& Loveland, 2014; Valtakoski, 2017). As Kowalkowski and Ulaga (2017) state, “simply adding ancillary service offerings to the core product portfolio does not change [...] the product-centric mindset with no genuine interest in the customer after the sale” (pp. 44-45). The transformation to servitization thus calls for the development of a service-oriented culture, among other things. Otherwise, it is likely to fail (Shah et al., 2006). Service-centricity requires that the approach to service provision be changed from reactive - waiting for sales leads - to 'proactive service management,' which is aimed at educating customers as well as predicting and preventing problems (Kowalkowski \& Ulaga, 2017, p. 47). Furthermore, the service offering has to be co-created with customers and equipment manufacturers. To deliver value-added services, IDs need to get buy-in, as well as facilitate an increased interaction and collaboration with equipment suppliers (Hakanen et al., 2017; Olsson et al., 2013; Rönnberg Sjödin, Parida \& Wincent, 2016). Despite this, detailed 
insights into the role of IDs in servitization are scant (Gadde, 2014; Hakanen et al., 2017; Story et al., 2017), which limits our understanding of the main challenges faced by servitizing IDs. An identification and successful resolution of such problems can determine ID's readiness to transition towards the provision of advanced services. Therefore, we attempt to contribute to the servitization literature by exploring the following research question:

RQ: What problems do independent distributors need to resolve to be ready to transition towards the provision of advanced services?

To answer this question, we draw upon an in-depth case study of a Business-to-Business (B2B) ID active in selling traditional industrial equipment. The ID sells packaging equipment and provides services for the food and beverage sector in the United Kingdom (UK) and has been struggling to successfully servitize for the past eight years. This ID is a particularly interesting case as they initiated the servitization transition themselves and encountered an array of problems in doing so.

Our paper makes two contributions. First, by empirically examining servitization problems from the perspective of the ID, we find that IDs, like manufacturers, can initiate servitization. During this transition they encounter a number of internal and ecosystem-related problems that differ to those faced by equipment manufacturers and manufacturer-owned dealers. We identify these by using three theoretical perspectives: stakeholder theory (Freeman, 1984; Freeman at el., 2010; Freeman, Harrison \& Wicks, 2010), the attention-based view (Ocasio, 1997, 2011), and organizational learning theory (Argyris, 1976) as our sensitizing concepts. This leads us to a categorization of servitization problems into (1) conflicting interests of key stakeholders, (2) a misalignment between distribution of managerial attention and servitization 
strategy, and (3) ineffective knowledge management within the ecosystem. Second, building on these groups of servitization problems, we propose a servitization-readiness decision tree with seven criterion that can be used by IDs to evaluate and improve their servitization efforts.

The paper proceeds as follows. The theoretical section focuses on the role of IDs in the distribution ecosystem and offers an overview of our three theoretical perspectives. The methods section explicates our approach, research design, and data-analysis procedures. We then report our empirical findings and further elucidate the proposed servitization criteria that form the decision tree. Finally, in the concluding sections, we elaborate the theoretical contributions, managerial implications, and limitations of our study.

\section{Theoretical background}

\subsection{The role of independent distributors in the servitization literature}

Historically, equipment manufacturers were regarded as 'channel captains' responsible for distribution arrangements (Revzan, 1961). Under this regime, independent distributors were perceived as a 'necessary evil' to support manufacturers' marketing strategies (Narus \& Anderson, 1987; Quinn \& Murray, 2005). This notion influenced the development of the servitization literature in so far as servitization initiatives were examined predominantly from the perspective of manufacturers and/or manufacturer-owned distributors (Hakanen et al., 2017; Kindström, Kowalkowski \& Sandberg, 2013; Story et al., 2017; Tuli, Kohli \& Bharadwaj, 2007). Almost six decades later, independent distributors still receive limited academic attention (Gadde, 2014; Olsson et al., 2013). When referring to IDs, researchers use terms such as 'industrial distributor,' 'middleman,' 'intermediary,' and 'wholesaler' interchangeably without clearly defining potential differences and without clarifying their role within the broader servitization ecosystem (Hakanen et al., 2017; Herbig \& O’Hara, 1994; 
Olsson et al., 2013; Story et al., 2017). In this paper, we consider IDs to be industrial "middlemen who buy goods from producers and resell them, along with a variety of associated services, to organizational [business] customers” (Herbig \& O’Hara, 1994, p. 199).

The importance of IDs has continuously been questioned in the global supply chain. So far, IDs have been able to justify their role mainly due to their flexibility to adjust to changing environmental conditions (Gadde, 2014; Olsson et al., 2013). IDs’ key competencies are geared toward a local economy, often a single market sector, which they have an excellent knowledge of and in which they have an established customer base. Business customers perceive them as less biased compared to manufacturer-owned dealers because IDs typically carry a broad range of product lines from many different equipment manufacturers. This enables them to shift from one product range to another or combine machines and equipment from more than one manufacturer to fully meet their customers' needs. Although IDs significantly differ from manufacturers and manufacturer-owned dealers (See Table 1), there are significant differences among IDs themselves (Gadde, 2014). While some IDs focus only on marketing and sales of physical goods on behalf of manufacturers, others are developing complex customized solutions. Under a product-dominant logic, the relationship between ecosystem actors is transactional, and the goal of IDs is to sell as many products to as many customers as possible (Olsson et al., 2013). In contrast, service-centric IDs prioritize customer retention over acquisition and devote a significant amount of time and resources to the development of customized value-added solutions. They invest in relationship-building activities with both equipment manufacturers and business customers (Parida et al., 2014). While service-centric IDs are thriving in the current business environment, their product-centric counterparts face difficulties to remain competitive. Increased pressure is put on distribution channels to integrate products with advanced services if they want to maintain their role in the supply chain (Gebauer 
\& Fleisch, 2007; Hakanen et al., 2017). This is because the role of IDs is not only to provide additional value for manufacturers (i.e., marketing, international sales, and distribution) but increasingly they also need to provide more value for their customers. It is evident that ID’s role as a mere re-seller of manufacturer's product is shifting to the provision of more customercentric solutions which requires IDs to develop engineering excellence and continuous improvement of the products and services they offer. Despite a changing distribution landscape, the focus of the research literature on servitization concerning IDs has been centered on equipment manufacturers’ capabilities (Chang \& Gotcher, 2010; Li, Cui \& Liu, 2017; Story et al., 2017) and challenges (Deligonul, Kim, Roath, \& Cavusgil, 2006; Nes, Solberg, \& Silkoset, 2007) when selling through IDs. For instance, Li et al. (2017) point to a manufacturer's level of absorptive capacity as an important factor in acquiring market knowledge from an ID. On the other hand, Nes et al. (2007) argue that national cultural distance can negatively impact trust and communication between an exporter and a foreign distributor. Furthermore, the authors suggest that the exporter's commitment to the foreign distributor is contingent upon its financial performance.

\section{<Please insert Table 1 here $>$}

The concentration on equipment manufacturers and manufacturer-owned dealers during servitization has drawn scholarly attention away from indirect distribution channels, which have a similar potential to servitize and thus can 'become coordinators of the total supply chain' (Dawson, 2007, p. 318). However, there are several significant differences in the servitization challenges being faced by equipment manufacturers, manufacturer-owned dealers, and IDs. For instance, IDs are positioned as intermediaries that operate in a complex ecosystem working with multiple equipment suppliers and serving diverse business customers. They build upon 
their existing resources and combine them with capabilities of their ecosystem partners in order to solve customer problems (Gadde, 2014). Each ID’s supplier has different business strategies, management styles and may be from a different cultural background.

\subsection{Exploring ID’s servitization challenges through sensitizing concepts}

\subsubsection{Stakeholder Theory}

Simply adding services to the existing product offering will not improve organizational performance (Kastalli \& Van Looy, 2013; Parida et al., 2014). The transition to provision of advanced services requires changes in the relationship between stakeholders in the servitization ecosystem, from transactional to more intense collaboration (Baines \& Lightfoot, 2013; Kowalkowski, Kindström \& Witell, 2011), which could allow deeper penetration, improved quality, decreased costs and enhanced learning (Gençtürk \& Aulakh, 2007). Therefore, we draw from stakeholder theory (Freeman, 1984; Freeman et al., 2010; Freeman, Harrison \& Wicks, 2007; Freeman, Wicks \& Parmar, 2004) to better understand how ID’s servitization initiatives affect and are affected by, its relationship with the key stakeholders within the ecosystem (Freeman, 1984; Stieb, 2008). The basic premise of stakeholder theory holds that value within the ecosystem is created and distributed through the collaboration of multiple stakeholders within the network (Stieb, 2008; Sirgy, 2002). We agree with Visnijic, Wiengarten and Neely (2016, p. 112) that the "delivery of complex solutions by a single company would require the company to take on high levels of uncertainty and perform well in a number of different, and often unrelated, product markets.” Arguably, no single organization has all the necessary expertise to find solutions to customers' complex needs, an establishment of collaborative business networks is being increasingly advocated (Filieri, McNally, O’ Dwyer \& O’Malley, 2014; Lush, Vargo \& Tanniru, 2010). Successful innovation in the distribution channel is dependent upon value-adding partnerships among the key parties (Anderson, Day 
and Rangan, 1997). It is precisely the joint efforts of the stakeholders within the network that lead to mutual value creation (Grönroos \& Helle, 2010; Prahalad \& Ramaswamy, 2003). In addition to building strong cross-border relationships, resource commitments together with the ability to integrate, learn, and co-create value will contribute to a successful collaboration among stakeholders (Håkansson \& Waluszewski, 2013; Kohtamäki, Partanen \& Möller, 2013; Möller \& Rajala, 2007; Ngugi, Johnsen \& Erdélyi, 2010; Opresnik \& Taisch, 2015).

For IDs to successfully servitize they have to create sufficient value for customers by offering solutions that are fully tailored to their needs and goals (Valtakoski, 2017). Therefore the longterm success of firms largely depends on their ability to satisfy the interests of those stakeholders who are closest to their operations (Freeman et al., 2007; Mitchell, Agle \& Wood, 1997). In contrast to manufacturers and manufacturer-owned dealers, IDs need to enable the collaboration among a larger number of stakeholders and respond to a much broader and often more diverse set of stakeholder interests. The IDs are not only responsible for addressing customers' needs, but also the needs of their multiple suppliers. This gives the ID a unique position as a central actor (Müller \& Seitz, 2012) that plays an essential role in the value cocreation process by catering to and balancing the interests of its core stakeholders to facilitate servitization. Stakeholder theory, is therefore, an important concept to aid examination of how ID can establish the required balance within the ecosystem.

\subsubsection{Attention-based View}

A transition from selling products to the provision of services put significant pressure on firms' existing processes, activities and organizational structures (Kowalkowski \& Ulaga, 2017). Firms need to be able to re-think and innovate their existing processes or develop new ones to support their servitization initiatives and new value proposition (Gebauer, 2009). However, 
organizational change is often hindered by existing structures that derail managers' attention away from its long-term strategic aims. Ocasio (1997, p. 202) postulates that "the ability of the firm to adapt successfully to a changing environment is conditional on whether the firm's procedural and communication channels focus the attention of organizational decision-makers on an appropriate set of issues and answers.” Therefore, with an aim to better understand the challenges that IDs face during the servitization, we draw upon the attention-based view. In essence, the attention-based view holds that managerial attention is just as limited as the firm's physical resources (Ocasio, 1997; 2011). Furthermore, “focused attention both facilitates perception and action towards those issues and activities being attended to and inhibits perception and action towards those that are not” (Brattström et al., 2018; Ocasio, 1997, p. 190). A shift in managerial attention toward servitization is often triggered by eroding product margins and increasing customer expectations (Gebauer, 2009), which to some extent apply to all manufacturers, manufacturer-owned dealers and IDs. However, due to their differences, managers in these firms are likely to experience different forces, barriers, and obstacles to redirecting their attention towards servitization.

The activities toward which managers' attention is distributed largely depends on the structure of the firm (Barnett, 2008). Therefore, the product-centric culture, norms, and values that are strongly embedded within organizational structures could impact the flow of managers' attention during the servitization initiatives. Arguably, it is a role of top and middle management to establish and support a service culture and, through incremental steps, initiate transition (Kowalkowski \& Ulaga, 2017; Oliva \& Kallenberg, 2003). However, their attention is strongly influenced by the firm's current organizational context and structure (Gebauer, 2009). For organizational change to be successful, managers' attention needs to be channeled in a way that allows them to "successfully attend to the relevant issues and answers" pertinent 
to pursued strategy (Ocasio, 1997, p. 204). This needs to be reflected in firms' long-term goals, strategies, activities, and behaviors.

Therefore, in this paper, we use attention-based theory to examine the residual impact of network's product-dominant logic on the distribution of ID's management's attention during the transition to a provision of advanced services. By building upon this theory, we aim to understand not only the impact of attention distribution on IDs' ability to successfully servitize but also the forces within the broader servitization ecosystem that are likely to shape its distribution.

\subsubsection{Ecosystem-wide Learning}

The importance of managing knowledge within the stakeholder networks motivated us to adopt the organizational learning perspective (Argyris, 1976) and examine not only the role that IDs play in network-wide learning but also the impact it has on their servitization success. In brief, the development of value-added solutions requires effective management and sharing of diverse knowledge among all stakeholders in the service delivery network (Parida et al., 2014), especially when a cross-border knowledge sharing between international partners is required (Poon, Evangelista \& Albaum, 2005). Given IDs‘ central position in the ecosystem, they are responsible for facilitating an effective flow of knowledge in ways that benefit all stakeholders. For instance, ID’s suppliers are reliant on its provision of customer insights (i.e., changing needs, usage feedback, trends) while ID’s customers depend on its ability to share equipment manufacturers' technical know-how with them (i.e., performance-related data, line extensions, repurposing of machines) (Rönnberg Sjödin, Parida \& Wincent, 2016). Therefore, the knowledge transmitted within the servitization ecosystem depends on ID’s ability to not only create extensive knowledge stocks but to successfully establish and manage diverse knowledge 
flows within the ecosystem (Fahey \& Prusak, 1998). As argued by Harrison and Wicks (2013, p.116), the "multiple sources of information about a particular stakeholder, where available, are better than relying on one source of information.” However, the multiplicity of stakeholders and the complexity of the ecosystem (Freeman et al., 2010) in which IDs operate can make this process rather challenging (Argyris, 1976). For instance, the equipment manufacturer might have insufficient knowledge about the needs of business customers (Valtakoski, 2017), while the end customer or user has limited knowledge about the capabilities and resources of the equipment manufacturer (Kohtamäki \& Partanen, 2016; Kohtamäki et al., 2013). Therefore, it is essential to understand how the ID’s central position within the ecosystem-wide knowledge management influences its ability to servitize.

\section{Methods}

\subsection{Research strategy}

Given the limited research on servitizing IDs, we adopted an abductive research strategy to allow for an in-depth understanding of this largely understudied phenomenon (Blaikie, 2007; 2010). An abductive research strategy implies an integrated approach to theory, literature, and emerging data (Dubois \& Gadde, 2002; 2014), allowing researchers to constantly move "back and forth between a set of observations and theoretical generalisations" (Tavory \& Timmermans, 2014, p. 4). Successful servitization requires collaboration with the key actors in ID’s ecosystem. Therefore, our empirical investigation is aimed at gaining rich, real-life accounts (Charmaz, 2006), employing an in-depth single case study in which the role of the ID is examined within their servitization ecosystem. 


\subsection{Research setting and data collection}

The case studied is an ID (FoodPak) engaged in packaging machinery for the food and beverage sector (NAICS Code 311 and 312) in the United Kingdom and their rather unsuccessful attempts to servitize over the past eight years. Managers at FoodPak initiated the servitization transition themselves as a response to growing competitive pressures within the home market. FoodPak has 32 employees and employs the largest service team in the sector (15 engineers nationwide). It offers a variety of customized services, ranging from continuous maintenance, 24/7 nationwide support, lean consulting, and preventive maintenance to bespoke full-service contracts. Currently, the company is introducing performance-based service solutions for foodpackaging companies. Despite these efforts, however, FoodPak sells mainly basic services alongside packaging machinery (predominantly installation, setup, and provision of spare parts) on behalf of equipment manufacturers from Italy, Germany, and Switzerland.

Our data collection was organized into five stages over a three-year period: exploratory data collection, focus group 1, semi-structured interviews, focus group 2, and finally a follow-up phase and feedback on preliminary findings. Table 2 provides an overview of each stage and informants involved. During the exploratory stage, we conducted five in-depth interviews, which was followed by focus group 1 with selected senior managers. Gained initial insights helped us to understand FoodPak's business practices, servitization strategy, and problems related to transition. In particular, we saw that FoodPak’s failed attempts to servitize spanned firm boundaries, which led us to conduct a broader, ecosystem-level analysis in subsequent stages. These insights, combined with those culled from the literature, including three theoretical perspectives, informed the development of an interview protocol. We then conducted an additional 27 in-depth, face-to-face semi-structured interviews with the ID's senior management team (19 interviews), three of their customers (4 interviews) and two major 
equipment suppliers (4 interviews). ID’s customers were chosen from their database of food sector companies with the aim to gain insights from diverse sub-sectors. We conducted interviews with a small family firm (a biltong producer) as well as two medium-sized companies (a premium biscuits producer and a pastry bakery) with whom FoodPak has ongoing working relationships. Also, we identified two main equipment suppliers, whose sales contribute 30 percent to ID’s revenues: a large premium Italian equipment manufacturer ( $20 \%$ of sales) and a medium-sized price-accessible Swiss equipment manufacturer ( $10 \%$ of sales). Additionally, we also attended ID’s sales pitches and quarterly senior management meetings and communicated regularly with most of the informants by email or phone. At the end of the semi-structured interviews stage, we held a focus group 2 to obtain informants' feedback on emergent findings.

\section{<Please insert Table 2 here $>$}

We used stakeholder theory (Freeman, 2008; Parmar et al., 2010), the attention-based view (Ocasio, 2011), and organizational learning theory (Argyris, 1976) as sensitizing concepts to help us set the direction for our study. These theoretical lenses served as a general sense of reference and guidance (Blumer 1954; Bowen 2006) rather than a 'fixed presentation of pregiven world' (Sandberg \& Tsoukas, 2011, p. 352). They thus enabled us to discover, understand and interpret ID’s servitization-readiness problems. Furthermore, we used sensitizing concepts to 'lay the foundation for the data analysis' (Bowen, 2006, p. 14) by examining first order categories and developing second order themes that then became the building blocks of our framework. For instance, after conducting initial interviews at FoodPak, we observed that its relationships with customers and suppliers were influencing the transition. Therefore, to better understand this impact we drew upon stakeholder theory to guide our further data collection and analysis, enabling us to elaborate on already identified servitization 
problems. Finally, at the end of our data collection, we held two consecutive feedback sessions during which we presented our preliminary findings to FoodPak. Throughout these stages, we received valuable comments that helped us to improve the servitization-readiness decision tree framework (see Figure 2).

\subsection{Data analysis}

We adhered to the principles of systematic combining (Dubois \& Gadde, 2002) to match theory (sensitizing concepts) with empirical observations (Eisenhardt, 1989; Strauss \& Corbin, 1994). Systematic combining allowed us to move back and forth between the data and the literature. Thus, we engaged in a nonlinear data analysis process in which "theoretical framework, empirical fieldwork, and case analysis evolved simultaneously” (Dubois \& Gadde, 2002, p. 554). All interviews and focus groups were recorded and transcribed. The edited transcriptions were enriched with meeting notes, emails, and observational notes and then uploaded into Atlas ti7 software for analysis.

The data collection and analysis took place simultaneously. As data were collected over several years, it allowed us to grasp and uncover significant and lasting servitization problems faced by FoodPak. The qualitative content analysis enabled us to take a holistic step-by-step approach to data analysis and to reduce the complexity of primary data by allowing categories to emerge from the data (Bryman, 2004). The content analysis was organized into three interrelated phases with feedback loops. First, we 'named’ the data by using provisional line-by-line codes that were converted into more substantive in vivo codes concerning internal and ecosystemrelated transition problems. These codes constituted the foundation for the development of the first-order categories used during the following stage. This stage consisted of comparison, grouping, and in-depth examination of the relationships among first-order categories and codes, 
to reduce them to the most salient. Memos and relationship diagrams were used extensively at this stage.

During the first two stages, two researchers worked independently, and 15\% of discrepancies in the first-order categories were further investigated and mutually agreed upon during a follow-up discussion. In the last stage, we established key second-order themes that form the building blocks of the decision tree framework. The associated first-order categories led to the development of the criteria for assessing independent distributors' readiness to servitize. During all three stages, we consulted the literature to test its potential for explaining emerging patterns, explore contradictions, and improve the overall rigor of our study. Our coding scheme is summarized in Figure 1.

\section{<Please insert Figure 1 here- Two-column fitting $>$}

\section{Results}

A transition to the provision of value-added services can be initiated not only by equipment manufacturers but also by IDs themselves. The case of the FoodPak clearly demonstrates this. While the transition was initiated internally, we found that successful servitization also requires support and active participation by all key stakeholders. Our empirical findings highlight the importance of identifying and addressing internal and ecosystem-related problems faced by an ID during the transition. We identified three distinct groups of servitization problems (based on second-order themes) at FoodPak: (1) conflicting interests of key stakeholders within the ecosystem, (2) misalignment between distribution of managerial attention and servitization strategy, and (3) ineffective knowledge management within the ecosystem. Table 3 presents an overview of the first-order categories, codes, and quotes that led to the development of these 
themes. The following sections describe FoodPak's servitization problems based on the emergent themes.

\section{$<$ Please insert Table 3 here $>$}

\subsection{Conflicting interests of key stakeholders within ecosystem}

Perhaps the greatest obstacle in FoodPak's servitization initiatives was the lack of support from its main product-oriented equipment suppliers. A vast majority of these suppliers treated FoodPak as a mere reseller of their packaging machinery to the UK market. This was reflected in suppliers' approach (i.e., success measurement based on transaction-focused KPIs - key performance indicators) to their global distributors, prioritizing those that were capable of generating more product sales at premium rates. Equipment suppliers imposed their predefined product-centric sales model onto FoodPak to generate more transactional sales. For instance, one of FoodPak's largest equipment suppliers presented a clear vision for FoodPak to help them increase the sales of their machines in the UK market.

"We are manufacturers, sellers and we provide the system. We are not interested in collaboration [with FoodPak], we are trying to be strong in the UK market and this is our main aim. At the moment only around 30\% of [FoodPak's] proposals [machine sale proposal] are successful. This is why we are trying to increase our presence in the UK market, as we see a lot of potential there.” (Sales Manager, I14)

Due to a limited number of equipment suppliers interested in entering the UK market, FoodPak was dependent on maintaining its contracts with existing suppliers. These suppliers with their product-dominant logic demanded FoodPak to seek and prioritize transaction over building a long-term relationship. However, in the market where customers are increasingly seeking 
value-added services, this approach led to a decreasing quote-to-sale ratio which consequently pushed FoodPak lower on suppliers' list of priorities. This compounded the problem.

"In comparison to other distributors, we sell less machines and this is reflected in how our [main] suppliers often treat us .... they prioritize and support distributors who can generate more product sales.” (Technical Manager, I9)

The lack of interest on the part of suppliers was further exacerbated by the fact that they did not profit from the service revenues generated by FoodPak. Paradoxically, FoodPak’s current revenue model (pricing structure) did not allow suppliers to profit from service contracts - that is, FoodPak largely failed to incentify suppliers to support their emerging servitization initiatives. This situation led to conflicting interests between FoodPak and their key suppliers, with each pursuing different business goals.

FoodPak served three distinct customer types: startups, small and medium-sized businesses, and large international food manufacturers. Although customers' product needs were similar, their service requirements were diametrically different. FoodPak devoted a significant amount of time and resources to selling to large manufacturers. These manufacturers had extensive inhouse technical departments capable of undertaking maintenance and repair work; hence, they were not interested in entering into service contracts with FoodPak.

"We struggle to sell service contracts to large companies. They have several technical people on the shop floor and we find it difficult to justify why they should enter into service contracts with us.” (National Sales Manager, I5) 
On the other hand, smaller businesses often lack sufficient internal technological skills, but the rather high entry prices of ID’s service contracts prevented them from signing up for services. These high entry prices were a result of lacking suppliers' interest in supporting FoodPak's servitization initiatives. Without suppliers' support and investment, FoodPak was forced to keep the prices high to recover its rather high investment into the provision of these services (i.e., additional training, human resources, time, and investment in technology). With the support from its core suppliers, FoodPak could have decreased the time and investment needed for the development of these solutions. By gaining access to necessary knowledge, resources and investment from its suppliers, FoodPak could offer more competitive pricing that would appeal to the underserved market segments (i.e., SMEs and family-owned firms).

“Our [main] suppliers have all the resources and the technical 'know-how' that we need to develop better services for our customers. But, they rarely share these with us so we often end up 'reinventing the wheel' and that costs us extra money." (General Manager, I1)

In addition, the majority of FoodPak's service contracts were based on the number of packaging equipment breakdowns, yet its customers profited only when machines were operating flawlessly. This created further conflicts within the network where FoodPak, nor its suppliers were incentivized to keep the machines in operation for as long as possible. In essence, customers’ goals and interests were overlooked in FoodPak’s servitization efforts. Currently, its suppliers only profit from machines/equipment sold. While FoodPak profits from machine sales too, it also generates additional revenue from services (i.e., fixing machine breakdowns, preventative maintenance or regular servicing). However, this additional revenue is not shared 
with manufacturers of these machines and, therefore, they lack a significant incentive to invest in and support FoodPak’s servitization.

Furthermore, besides regular service contracts, ID’s customers were also interested in increasing machine's utilization by extending its flexibility and modularity. However, this position could not be supported by FoodPak due to its mostly transaction-based relationships with equipment suppliers. In essence, FoodPak could not adequately support customers' growing needs because, in order to do so, it would need to integrate and closely collaborate with its diverse suppliers. However, FoodPak kept failing to create the conditions that are necessary for suppliers to support its servitization initiatives.

\subsection{Misalignment between distribution of managerial attention and servitization strategy}

Data analysis uncovered a significant conflict between how the attention of managers is distributed toward operational and governance related activities within FoodPak. While top management had put transition plans into place (governance), ID’s business functions (operations) and their activities were driven by both customer and supplier demands. The attention of middle management was directed towards dealing with ad-hoc issues that were deemed important by dominant suppliers rather than ID’s top management. This caused significant conflict in managerial focus where day-to-day activities and projects pursued by different functions did not reflect on and were not connected to the overall FoodPak's strategic vision.

This disconnect between what needed to be done and what was actually being done was caused to a large extent by lacking unity between ID’s internal functions. Each business function was aimed at individual targets without considering other functions and the broader impact their 
actions had on FoodPak's servitization initiatives. In essence, each function was acting as a separate entity within a large network, and instead of being united by the ID's vision each instead pursued its own agenda by responding to different forces within the wider network. This caused significant bottlenecks at FoodPak where each function was prioritizing different projects. Managers of each function tried to implement an incentive scheme as a means of reducing departmentalism. However, the success was meager because the initiative was not aimed at uniting these functions (governance) but instead rewarding them for achieving specific operational goals. For example, the sales function focused on increasing product sales while the engineering function was incentified to increase the speed at which the quotes were delivered to potential customers. Only the marketing function was concerned with developing customer relationships during all touchpoints.

FoodPak's salespeople were the main point of contact with customers, acting as both sales agents and key account managers for existing customers. However, the sales function's incentive scheme led the sales team to prioritize a potential 'big sale' over nurturing its relationship with existing customers. The sales team focused solely on producing quotes and selling machines, as they did not directly benefit from the sales of services. In other words, their operational focus and incentives were not connected to the FoodPak's overall vision. Furthermore, FoodPak continued to impose sales-based KPIs on its teams.

“To me, maintaining a good relationship with our customers is key. I am trying to do this but I don't have support from other departments...we [FoodPak] say one thing but we end up doing another.” (Marketing Manager, I2) 
Another substantial obstacle to transition that we observed at FoodPak was a fear of failure, which was firmly embedded in the organizational culture and management style. Nobody was willing to assume full responsibility, and therefore ID’s business functions, when making decisions, often restored to the more familiar product-centric logic over uncertain and complex service-centric logic, which further grew the divide between ID’s governance and operational focus.

\subsection{Ineffective knowledge management within the ecosystem}

Almost all informants referred to an outdated CRM (customer relationship management) system that they sparingly used for inserting customer information. This ad hoc approach resulted in a lack of overall understanding of customer needs, beyond the purely technical details required to customize the packaging equipment. Each function collected, prioritized, and separately stored different types of customer information. In doing so, they created internal "knowledge silos" that led to inefficiencies in managing customers and communicating with suppliers. As a result, FoodPak failed to capture and add value to the overall knowledge stock within its ecosystem; customers did not benefit from knowledge gathered from suppliers, and vice versa.

Salespeople did not record, codify, or disseminate the knowledge gathered during customer encounters. In this sense, the sales team acted as a gatekeeper for customer knowledge. Essentially, any information beyond the technical specification of required machinery remained in salespeople's notebooks or minds, even when they moved to other companies. As a consequence, FoodPak failed to become sufficiently acquainted with its customers over time and missed many opportunities to develop a relevant value-added service portfolio. FoodPak’s failure to capture and codify this knowledge was due partly to the use of outdated technologies that did not allow for effective knowledge gathering, management, and dissemination (i.e., 
sharing with ecosystem actors). This climate of 'technophobia' was supported by short-term financial targets, a poor understanding of new technologies and their potential, and a crossfunctional unwillingness to use such technologies.

Despite FoodPak's transactional relationship with equipment suppliers, some of these suppliers regularly offered training at their headquarters (mainly in Italy) for salespeople and engineers. The sessions, of two to three days' duration, included intensive training in the features and flexibility of existing and newly developed machines. However, FoodPak did not have a codification policy in place to capture and benefit from this knowledge in the long term. Therefore, not only was the knowledge of no benefit for non-sales functions, but it was apt to be forgotten by salespeople and engineers due to information overload. The Account Manager at one of ID’s major equipment suppliers expressed the need to increase FoodPak's technical knowledge of their machines as one of their key plans to help FoodPak to improve their performance.

"We hope that every sales manager and everyone who is in charge of technical issues will be competent to sell our machines. Our aim is to try to teach them with some other trainings so they know everything about our machines. This will be helpful for us, as it will mean we can leave the UK market in their hands and concentrate somewhere else." (Account Manager, I15) 


\section{Resolving servitization problems: Towards a servitization-readiness decision tree}

The first-order categories and second-order themes were used as the basis for developing a servitization-readiness decision tree, shown in Figure 2. The purpose of the decision tree is to provide an easily applicable set of hierarchically arranged questions (criteria) to help IDs evaluate their readiness to transition from being product-centric to being providers of advanced services. The decision tree enables IDs to diagnose different types of servitization problems and thereby establish priorities - issues that require immediate attention before the company moves forward with its transition initiatives.

\section{<Please Insert Figure 2 here- Two-column fitting>}

Our data analysis identified seven core criteria to be met before embarking on servitization journey. We combined insights from our empirical observations, servitization literature and three theoretical perspectives (stakeholder theory, attention-based view and organizational learning theory) to develop draft versions of the decision three. Afterward, we refined and corroborated emergent versions of the framework through follow-up workshops with FoodPak. Subsequently, we grouped the criteria into three categories: (1) stakeholder alignment, (2) managerial attention to transition, and (3) stakeholder knowledge management. Lastly, we derived servitization problems from ID’s inability to meet the identified criteria.

These criteria are ordered hierarchically to demonstrate the interdependence among them. For instance, if ID cannot gain support from its core suppliers, and buy-in from the customers (category one: stakeholder alignment), pursuing an organizational change to divert the attention of managers toward servitization (category two: managerial attention to transition) will deem irrelevant. We have seen this in the case of FoodPak, where company for several years has 
been trying to re-shape its internal environment to support its servitization ambitions just to face the roadblock at later stages in the form of stakeholders' reluctance to support this transition. Without aligning their interests first, the structure that FoodPack developed while being internally sound, was unable to integrate and address its stakeholders' varied needs. Equally, without stakeholder alignment and organizational structure that allows for distribution of managerial attention toward servitization, the ID will not be able to establish effective knowledge management strategies and processes across the value network (category three: stakeholder knowledge management). In an ideal scenario, an ID must meet all seven criteria in order to be ready for a successful transition. However, the criteria cannot be 'skipped' and returned to later, but instead, IDs need to follow them in the prescribed sequence to deal with the identified issues in the most effective way possible.

The first criterion is gaining active support of ID's key equipment suppliers during the transition. Usually, it is the equipment manufacturers that initiate servitization (Baines \& Lightfoot, 2013). In our case, however, it was the ID that initiated the transition. For ID to be ready to servitize it first needs to establish a fine balance between the interests of equipment suppliers and its organizational strategies (Freeman et al., 2010). In contrast to manufacturerowned dealers, IDs serve multiple suppliers whose strategies often differ from one another. Therefore, the level of support from each will be considerably different. As argued by Mohr, Fisher and Nevin (1996, p. 103), when the equipment supplier imposes a high level of integration and control over its IDs, they will 'surrender to the decision making authority' of the manufacturer. The importance of ID to the equipment manufacturer is likely to increase once it accounts for a greater amount of the manufacturer's revenue in a particular foreign market (Kim, 2001). Given the importance of co-creation between the equipment manufacturers and ID during the process of servitization, all stakeholders will have to make a 
significant resource and time investment into the transition (Freeman et al., 2010). In particular, IDs are dependent upon the manufacturers' provision of an in-depth technical and service training. In the case of FoodPak, its major product-centric equipment suppliers were not willing to support its transition due to FoodPak's failure to introduce compelling incentives for these suppliers to benefit from its servitization initiatives.

Therefore, the second criterion is to align ID's and its key suppliers' goals and incentives associated with the transition. Given the critical role played by ID’s key suppliers in supporting its transition, it is ID’s responsibility to incentify these suppliers (i.e., revenue sharing) and to establish common servitization goals. As argued by Freeman et al. (2010, p. 34), in ecosystems in which stakeholders have diverse interests, the role of the central actor is to "redefine, redescribe, or reinterpret stakeholder interests so that [it] can figure out a way to satisfy both.” If the ID and equipment supplier have a long-term relationship, both parties can benefit from improved process performance, decreased costs and enhanced learning (Gençtürk \& Aulakh, 2007).

Given the ID’s central role within the ecosystem, after securing suppliers' buy-in it must ensure that its goals and incentives are aligned with those of its customers. This leads to the third criterion in the decision tree. Traditionally, customers perceived IDs only as re-sellers and providers of basic services. Therefore, to achieve alignment, the ID will have to first establish itself as a competent and knowledgeable technical expert. Secondly, the ID will need to develop a means of sharing risks and profits with its customers (i.e., result-based pricing) that will lead to the pursuit of common goals (i.e., performance-based KPIs). Currently, FoodPak’s service revenues come predominantly from attending to machine breakdowns. However, customers aim to minimize breakdowns and achieve higher utilization of the machinery. These conflicting 
interests have prohibited FoodPak from servitizing successfully. It is imperative that customers' successes and failures become the ID's successes and failures as well. This alignment can be achieved only by working toward common goals. By aligning their goals with those of their customers, IDs can move 'roughly in the same direction' (Freeman et al., 2010, p. 23) and thus to dynamically adjust to the changing service needs of their customers. In essence, IDs need to develop a servitization offering that mirrors their customers' goals and strategic objectives (Maignan \& Ferrell, 2004). They can do so by treating customers as external stakeholders (Sirgy, 2002) and involving them in their corporate decisions (PlazaÚbeda, de Burgos-Jimenéz \& Carmona-Moreno, 2010).

The fourth criterion highlights the importance of achieving commitment to transition reflected in both ID's strategy (governance) and its existing processes and activities (operational). Servitizing manufacturers often develop a separate front-office that is responsible for service provision and managing relationships with customers (Baines \& Lightfoot, 2013). However, servitizing IDs need to introduce the service logic across all of their existing departments. In contrast to manufacturers, this can create challenges for IDs to channel attention towards servitization initiatives. In the case of FoodPak, this was manifested in day-to-day activities and processes (operational attention) that were not congruent with the overall servitization strategy (governance attention). This discrepancy was not only caused by the residual impact of FoodPak's former product-centric organizational structure, but also by the organizational structures of its dominant suppliers, who were imposing their vision to increase transactional sales in the UK market onto FoodPak. Ocasio (1997) suggests that distribution of managerial attention depends upon the organizational structure of the firm, however, and as our case demonstrates this distribution is also significantly impacted by the dominant stakeholders within the network. 
The fifth criterion points to the importance of aligning and incentifying all ID functions to support transition. It is usually ID’s service team and sales team that have primary contact with customers, while the technical team communicates predominantly with equipment suppliers. This often leads to the pursuit of different and often conflicting goals within ID’s functions. As a result, each function prioritizes and promotes its own agenda, further hindering ID’s overall servitization efforts. Therefore, the lack of incentives to support unified servitization goals across the entire organization can lead to internal competition (conflicting interests), as clearly illustrated in the case of FoodPak. For servitization to succeed, IDs need to consider all departments as internal stakeholders (Lenka, Parida, Rönnberg Sjödin \& Wincent, 2018a; Sirgy, 2002), and involve them equally in corporate decisions to establish common goals (Plaza-Úbeda et al., 2010).

The sixth criterion is ID's digitalization capabilities to collect, analyze and unify data within the ecosystem. ID’s ability to successfully servitize resides in its ability to not only collect data within the ecosystem but through analysis and unification turn it into actionable knowledge. Before embarking on servitization journey, ID needs to develop and maintain expert technical knowledge of the machines it sells, and this can only be achieved through continuous learning and access to information from both their core suppliers and customers. Digitalization thus plays a critical role in preparing ID for a successful transition. Therefore, it should be ID's priority to develop and integrate suitable technological solutions to support their stakeholders within the ecosystem. ID's central role within the ecosystem requires it to manage and unify data inflow from multiple diverse sources (e.g., a complex network of equipment suppliers present in foreign countries, customers in different industries). In the case of FoodPak, this proved to be somewhat problematic due to several factors. First, there was internal resistance to the adoption of new technology, which prohibited FoodPak to use a common platform and 
made data unification difficult and labor intensive. Second, many customers were unable to share all the necessary data with FoodPak, because the company lacked technological abilities to integrate this data into its existing systems. Finally, FoodPak experienced difficulties to gain access to detailed technical data from its core suppliers because of the transactional nature of their relationship that was reflected in lacking trust (e.g., fear of misuse of data, knowledge leakage). As argued by Harrison, Bosse and Phillips (2010), transparency and trust increase the likelihood of stakeholders to share information with firm, which is prerequisite for future success and collaboration with these stakeholders.

The last criterion in our decision tree is ID's ability to facilitate knowledge transmission between equipment manufacturers and customers in real-time. Given IDs' central role within the ecosystem, it needs to ensure a seamless flow of knowledge among key stakeholders, while eliminating any potential bottlenecks or barriers. To achieve this, IDs need to develop their communication system that will enable real-time monitoring of the performance of the machines in-use and at the same time sharing this information, in the adequate forms, with the equipment manufacturers and customers. This will enable IDs to not only promptly respond to potential issues (i.e., preventative maintenance, performance optimization), but also to add value to their stakeholders by providing them with relevant and actionable knowledge. This continuous flow of machines’ performance data from multiple customers can simultaneously help equipment manufacturers to improve and innovate their offering (Baines \& Lightfoot, 2013). In our case, FoodPak was collecting rich customer data from multiple sources. However, it did not share this knowledge with the equipment manufacturers due to its inability to unify these insights. Each function within the FoodPak was collecting a distinct set of data from customers using different systems and protocols to do so. This incongruence led to duplicate entries which created significant challenges in unifying these data and thus, directly benefiting 
from it. As a result, FoodPak only shared transactional data with its suppliers, which was insufficient for deriving any actionable insights. Also, as shown in our case, IDs need to be more receptive to additional knowledge offered by customers and encourage them to share such knowledge. However, FoodPak's customers could not see the benefits of sharing additional information (i.e., new product development plans, line extension, additional machine data, real-time performance data) with the company. The complexity of the knowledge-sharing process can lead to knowledge-sharing asymmetries among actors in the ecosystem (Bäck \& Kohtamäki, 2015).

\section{Discussion}

The servitization literature is currently so narrowly focused on servitizing manufacturers (Ulaga \& Loveland, 2014; Ulaga \& Reinartz, 2011), that it has diverted scholarly attention from the other actors within the distribution network who can be equally capable of initiating servitization (Kowalkovski \& Ulaga, 2017). In particular, servitization attempts initiated by IDs have been largely overlooked, and as a result, their role in the servitization ecosystem is still poorly understood. This is somewhat surprising because IDs have played an essential role in supporting equipment manufacturers for decades (Hakanen et al., 2017; Olsson et al., 2013).

We respond to Story et al. (2017)'s call for future research to provide insights into the role and capabilities of intermediaries in servitization. Our findings suggest that B2B IDs of industrial equipment are capable of initiating servitization themselves. But during the transition, they face a number of internal and ecosystem related problems that differ from those of servitizing manufacturers. By drawing on three theoretical perspectives: stakeholder theory (Freeman at al., 2010); the attention-based view (Ocasio, 1997, 2011) and organizational learning theory (Argyris, 1976) as our sensitizing concepts, we were able to group servitization problems that 
IDs face into three categories: (1) conflicting interests of key stakeholders within ecosystem, (2) misalignment between distribution of managerial attention and servitization strategy, and (3) ineffective knowledge management within ecosystem.

\subsection{Theoretical contributions}

Our study primarily contributes to the emerging discourses in the servitization literature by extending our understanding of servitizing IDs by examining the problems they encounter during transition. While the importance of IDs within supply chains is well-documented in the literature, the insights into their roles during servitization are scant (Gadde, 2014; Gençtürk \& Aulakh, 2007; Olsson, 2013). Extant literature assumes that IDs, as well as manufacturerowned dealers, are equally equipped to servitize. This underlying assumption has led to the suppression of differences between the two, creating an impression that they assume identical roles during the servitization. Just because IDs, as well as manufacturers and manufacturerowned dealers, can initiate the servitization (Benedettini et al., 2015; Ulaga \& Loveland, 2014; Valtakoski, 2017), it should not be assumed that they all play the same role, operate by the same logic, and encounter the same problems during the transition. As our findings suggest, these problems are contingent not only upon their distinct position within the servitization ecosystem, but they are also influenced by the nature of the relationships they have with other channel members.

Our case further reveals that the heterogeneity of needs and goals of ID’s diverse stakeholders pose a particular challenge during servitization. IDs often experience, and need to deal with the tension within their network in which the goals of their suppliers are in direct conflict with those of their customers and sometimes even their own (Freeman et al., 2010). Building upon stakeholder theory (Freeman, 1984; Freeman et al., 2007) as our sensitizing concept we found 
that for servitization to be successful IDs need to ensure that the goals and interests of their key stakeholders are aligned. In contrast, the stakeholder alignment seems less critical when manufacturers initiate the servitization as manufacturers often assume a dominant position within the supply network and have a capacity to vertically integrate their suppliers (Baines \& Lightfoot, 2013). IDs occupy weaker grounds within the supply network and, as we have seen in our case, are often heavily reliant on a few large equipment manufacturers who are responsible for the majority of IDs' revenues. Therefore, obtaining support from these core manufacturers is essential and represents a foundational step toward a successful transition to the provision of advanced services. As demonstrated in our case, suppliers will refuse to support transition initiated by ID unless they can directly or indirectly profit from the service revenues generated by the ID.

Additionally, our analysis suggests that IDs often struggle to shift towards the provision of advanced services due to the residues of a product-centric logic that is further solidified through their existing organizational structure. Although equipment manufacturers are likely to face a similar challenge (Brax, 2005; Oliva \& Kallenberg, 2003; Valtakoski, 2017), they can resolve it by establishing a separate front-office department that is responsible for the provision of advanced services (Baines \& Lightfoot, 2013). In contrast, IDs are argued to be service-centric by design (Li et al., 2011; Story et al., 2017). As a result, this has derailed scholarly attention from further examining IDs service-logic, leading to the generally accepted assumption that they are ‘servitization-ready’ by default. However, IDs service strategy usually revolves around manufacturers' strategic goals (e.g., installation of machinery, regular maintenance or operator training), instead of being focused on directly addressing their customers' existing and future needs. This inclination is reflected in IDs' organizational structure and further manifested through their processes and activities that emphasize manufacturers' requirements over those of their customers. Therefore, to servitize successfully, IDs need to redirect their strategic focus 
from manufacturers to customers, but they need to do so in the realm of their existing organizational structure.

However, as put forward by attention-based view scholars (Ocasio, 1997, 2011) an organizational structure directly influences the flow of managerial attention within the organization. For servitizing IDs, this is significant because their attention needs to be directed toward the pursuit of servitization strategy, often experiencing conflict between what they need to do and what their organizational structure allows them to do. As shown in our case such scenario was manifested through several conflicts and trade-offs between pursuing the transition (customer-centricity) and responding to pressing day-to-day issues (manufacturercentricity). Our findings suggest that the distribution of managerial attention besides being influenced by ID’s existing organizational structure is also contingent upon the organizational structures of its dominant suppliers and the overall structure of the supply chain in which they operate. Therefore, we propose that the distribution of ID's managerial attention during servitization is partially influenced by the structure of the entire servitization ecosystem. Based on these observations we suggest that the attention-based view (Ocasio, 1997, 2011) as a theoretical lens for understanding the flow of managerial attention within a firm can be further extended - and to a certain extent applied - at the network level. We believe that the attentionbased view has the potential to advance our understanding of how the structure of ecosystems impacts the distribution of managerial attention in firms that operate within.

Last but not least, servitizing IDs need to be able to develop, manage and integrate multiple communication channels to facilitate knowledge transmission within the broader servitization ecosystem. However, only after establishing alignment of core stakeholders goals and interests, and re-directing the managerial attention toward issues and goals pertinent to servitization, will allow IDs to establish effective, ecosystem-wide communication. As shown in our case, the 
ID did not only needed to adopt and integrate an appropriate technology (e.g., CRM, ERP, and other ITC systems) but also to overcome the barriers related to lack of trust within its servitization ecosystem. Traditionally, manufacturers have had a somewhat negative perception of IDs, claiming that they may be favoring competitor's products and leak critical information (Cespedes \& Corey, 1990). This lack of trust has impacted the amount and quality of data and information shared between IDs, and suppliers leading to significant 'information asymmetries’ (Kohtamäki \& Partanen, 2016; Kohtamäki et al., 2013; Valtakoski, 2017). Equally, for customers to benefit from advanced services, they need to share their operational data and internal knowledge, which also demands a high level of trust toward the IDs. To establish a higher level of trust among stakeholders, IDs need to increase transparency within their servitization ecosystem (Harrison et al., 2010).

\subsection{Managerial implications}

To assess ID’s servitization initiatives we developed a diagnostic tool - the servitizationreadiness decision tree. We created this tool in response to Baines, Lightfoot, Benedettini, and Kay (2009)'s call for more prescriptive approaches that focus on specific problems and guide managers in solving them. We postulate that before embarking on the servitization journey and committing resources, IDs need to first assess their readiness to implement such transition. Doing so will allow them to understand, examine and build foundations prerequisite for successful servitization. Therefore, a practical contribution of the decision tree resides in the identification and explication of the seven criteria for assessing IDs' readiness to servitize. We grouped these criteria into three categories: (1) stakeholder alignment, (2) managerial attention to transition, and (3) stakeholder knowledge management. Each criterion is assessed using two dichotomous answers (Yes-No) that help IDs to navigate through the decision tree. The criteria are presented in a hierarchical order, which means that unless IDs can meet the first set of 
criteria (Stakeholder Alignment), there is little point in moving onto addressing other two groups of servitization readiness criteria. For instance, investing time and resources into improving the stakeholder knowledge management will not yield much success without first aligning the stakeholders' interests or re-directing the managerial attention toward issues and goals pertinent to servitization. Our study shows that the most critical criteria for IDs to be ready to servitize is the alignment of goals and incentives of all major stakeholders within the servitization ecosystem. In other words, IDs need customers who are receptive to and can benefit from their advanced-services offering, and suppliers who are supportive of and can profit from their servitization ambition. Nevertheless, the main challenge is to eliminate potential conflicts of interest and exploitative behavior at either side of the supply chain and ultimately achieve a balance between what benefits suppliers, customers, and IDs themselves. To do so, IDs need to assume the role of a central actor to orchestrate and facilitate transactions and relationships within its servitization ecosystem in order to keep 'all primary stakeholders interests going in the same direction' (Freeman et al., 2007, p. 54).

The decision tree has several implications. Firstly, before developing and committing to servitization strategy, it is imperative that managers ensure that ID’s goals and incentives are aligned with those of key stakeholders in the servitization ecosystem. By aligning the firm's incentives with customers’ goals, managers will not only develop more relevant offerings, but also establish a strategic and mutually beneficial long-term relationship with them. For servitization to be viable, managers need to secure the support of key equipment suppliers. They have to develop mechanisms through which their suppliers can directly benefit from servitization. This would require IDs to experiment with different revenue models that are based on profit- and risk-sharing agreements. Furthermore, in order to establish solid foundations for servitization, IDs must consider knowledge as a strategic organizational asset. 
Managers need to introduce congruent and holistic processes for data collection, unification, as well as diffusion of knowledge within the ecosystem. Through these processes, they will ensure that the ID can collect and analyze data from diverse sources and multiple customer touch points. Lastly, since managers play a crucial role in initiating, managing, and supporting servitization, they need to change organizational structures that would then allow for appropriate distribution of their attention to areas that are critical to servitization success. In other words, managers must ensure that day-to-day operations are the reflection of their overall servitization strategy (i.e., firms' KPIs and internal measures of success). At the same time, the decision tree can also be used by other ecosystem actors collaborating with IDs under an indirect distribution channel regime. For example, manufacturers initiating servitization could use the decision tree to evaluate IDs readiness to support their transition.

\subsection{Limitations and future directions}

The primary aim of our study was to examine servitization problems from the perspective of the B2B ID of industrial equipment. By choosing ID that has been struggling to servitize for our case study, we have been able to uncover key challenges that IDs are likely to encounter during this transition. As we have established in our study, these challenges are the direct manifestation of IDs lacking readiness to servitize and should be identified and addressed prior to IDs beginning their servitization journey. Doing so will not only create solid foundations for servitization, but it will also increase its likelihood of success.

In addition to collecting data from ID's managers, we have also conducted a number of interviews with their customers and equipment suppliers to gain more insights into relationships within ID’s stakeholder network. As identified in our study, these stakeholders play an essential role in ID's servitization initiatives. Therefore, we suggest that future studies 
should focus on uncovering reasons and motivations of various stakeholders to support IDs' transition. Because our insights are limited to a single case of the ID that operates in the food packaging sector in the UK market, we recommend that future research adopt a more quantitative approach. Future empirical studies could take a confirmatory approach and seek to validate the servitization-readiness decision tree and extend it to include other criteria and more fine-graded categories. Servitization problems experienced by IDs could differ as a result of their industry and country context. For example, in some low-technology sectors, a shift from selling products to the provision of advanced services may be relatively new to IDs operating in food and drink industry, as demonstrated by the case of FoodPak. However, our findings are of limited value to high-technology industries (e.g., digital, pharmaceutical, servers, and network systems) that are at the forefront of servitization and experience distinct servitization challenges. They operate in more fluid industries that are reshaped continuously by stakeholders ranging from large system integrators to small product-centric firms.

While our study focused on uncovering problems faced by servitizing IDs during the transition, offering remedies for these problems is beyond the scope of this paper. Further research is therefore needed to provide guidance on how to resolve the servitization problems presented in our study. In particular, we would welcome research focusing on goal alignment and knowledge sharing among key stakeholders during servitization. Researchers can provide more comprehensive insights by integrating stakeholder and organizational learning theories to answer the following questions: What stakeholder engagement strategies can ID implement to gain support from its key stakeholders during the transition? How can ID ensure seamless flow of knowledge within its complex network of customers and equipment suppliers? How would ID’s servitization problems differ if the equipment supplier initiated the transition? Finally, in the light of our findings, we propose future longitudinal studies to focus on the development 
of a roadmap that will illustrate the process of ID’s transition journey towards servitization, from inception and readiness to the provision of advanced services. This roadmap could complement our servitization-readiness decision three in providing practitioners with actionable guidance on implementation once the ID is ready to servitize. 


\section{References}

Anderson, E., Day, G. S., \& Rangan, V. K. (1997). Strategic channel design. Sloan Management Review, 38(4), 59. Retrieved from:

https://repository.upenn.edu/marketing_papers/401

Argyris, C. (1976). Increasing leadership effectiveness. New York: Wiley.

Bäck, I., \& Kohtamäki, M. (2015). Boundaries of R\&D collaboration. Technovation, 45, 1528. https://doi.org/10.1016/j.technovation.2015.07.002

Baines, T. S., \& Lightfoot, H. (2013). Made to serve: How manufacturers can compete through servitization and product-service systems. Chichester: Wiley.

Baines, T. S., Lightfoot, H. W., Benedettini, O., \& Kay, J. M. (2009). The servitization of manufacturing: A review of literature and reflection on future challenges. Journal of Manufacturing Technology Management, 20(5), 547-567.

https://doi.org/10.1108/17410380910960984

Barnett, M. L. (2008). An attention-based view of real options reasoning. Academy of Management Review, 33(3), 606-628. https://doi.org/10.5465/amr.2008.32465698

Bello, D. C., Chelariu, C., \& Zhang, L. (2003). The antecedents and performance consequences of relationalism in export distribution channels. Journal of Business Research, 56(1), 1-16. https://doi.org/10.1016/S0148-2963(01)00215-6

Benedettini, O., Neely, A., \& Swink, M. (2015). Why do servitized firms fail? A risk-based explanation. International Journal of Operations and Production Management, 35(6), 946979. https://doi.org/10.1108/IJOPM-02-2014-0052

Blaikie, N. (2007). Approaches to social enquiry. Cambridge: Polity Press.

Blaikie, N. (2010). Approaches to social enquiry (2nd ed.). Cambridge: Polity Press.

Blumer, H. (1954). What is wrong with social theory? American Sociological Review, 18, 310. https://www.jstor.org/stable/2088165

Bowen, G. A. (2006). Grounded theory and sensitizing concepts. International Journal of Qualitative Methods, 5(3), 12-23. https://doi.org/10.1177/160940690600500304

Brattström, A., Frishammar, J., Richtnér, A., \& Pflueger, D. (2018). Can innovation be measured? A framework of how measurement of innovation engages attention in firms. Journal of Engineering and Technology Management, 48 (April-June), 64-75. https://doi.org/10.1016/j.jengtecman.2018.04.003

Brax, S. (2005). A manufacturer becoming service provider - challenges and a paradox. Managing Service Quality: An International Journal, 15(2), 142-155. https://doi.org/10.1108/09604520510585334

Bryman, Alan (2004). Social research methods (2nd ed.). New York: Oxford University Press. 
Cennamo, C., Berrone, P., \& Gomez-Mejia, L. R. (2009). Does stakeholder management have a dark side? Journal of Business Ethics, 89(4), 491-507.

https://doi.org/10.1007/s10551-008-0012-X

Cespedes, F. V., \& Corey, E. R. (1990). Managing multiple channels. Business Horizons, 33(4), 67-78.

Chang, K. H., \& Gotcher, D. F. (2010). Conflict-coordination learning in marketing channel relationships: The distributor view. Industrial Marketing Management, 39(2), 287-297.

https://doi.org/10.1016/j.indmarman.2008.10.003

Charmaz, K. (2006). Constructing grounded theory: A practical guide through qualitative research. London: Sage.

Dawson, J. (2007). Wholesale distribution: The chimera in the channel. International Review of Retail, Distribution and Consumer Research, 17(4), 313-326.

https://doi.org/10.1080/09593960701507468

Deligonul, S., Kim, D., Roath, A. S., \& Cavusgil, E. (2006). The Achilles heel of an enduring relationship: Appropriation of rents between a manufacturer and its foreign distributor. Journal of Business Research, 59(7), 802-810. https://doi.org/10.1016/j.jbusres.2005.11.004

Dubois, A., \& Gadde, L. E. (2002). Systematic combining: An abductive approach to case research. Journal of Business Research, 55(7), 553-560. https://doi.org/10.1016/S01482963(00)00195-8

Dubois, A., \& Gadde, L. E. (2014). “Systematic combining” - A decade later. Journal of Business Research, 67(6), 1277-1284. https://doi.org/10.1016/j.jbusres.2013.03.036

Eisenhardt, K. M. (1989). Building theories from case study research. Academy of Management Review, 14(4), 532-550. https://doi.org/10.5465/amr.1989.4308385

Fahey, L., \& Prusak, L. (1998). The eleven deadliest sins of knowledge management. California Management Review, 40(3), 265-276. https://doi.org/10.2307/41165954

Fein, A. J., \& Anderson, E. (1997). Patterns of credible commitments: territory and brand selectivity in industrial distribution channels. The Journal of Marketing, 19-34. https://www.jstor.org/stable/1251828

Filieri, R., McNally, R. C., O'Dwyer, M., \& O'Malley, L. (2014). Structural social capital evolution and knowledge transfer: Evidence from an Irish pharmaceutical network. Industrial Marketing Management, 43(3), 429-440. https://doi.org/10.1016/j.indmarman.2013.12.011

Frazier, G. L., Maltz, E., Antia, K. D., \& Rindfleisch, A. (2009). Distributor sharing of strategic information with suppliers. Journal of Marketing, 73(4), 31-43.

https://doi.org/10.1509/jmkg.73.4.31

Freeman, R. E. (1984). Strategic management: A stakeholder approach. Boston: Pitman. 
Freeman, R. E. (2008). Managing for stakeholders. In T. Donaldson \& P Werhane (Eds.), Ethical issues in business: A philosophical approach (8th ed.) (pp. 39-53). Englewood Cliffs, NJ: Prentice Hall.

Freeman, R. E., Harrison, J. S., \& Wicks, A. C. (2007). Managing for stakeholders: Survival, reputation, and success. Cloth: Yale University Press.

Freeman, R. E., Harrison, J. S., Wicks, A. C., Parmar, B. L., \& De Colle, S. (2010). Stakeholder theory: The state of the art. Cambridge: Cambridge University Press.

Freeman, R. E., Wicks, A. C., \& Parmar, B. (2004). Stakeholder theory and "the corporate objective revisited”. Organization science, 15(3), 364-369.

https://doi.org/10.1287/orsc.1040.0066

Gadde, L. E. (2014). Distribution network dynamics and the consequences for intermediaries. Industrial Marketing Management, 43(4), 622-629.

https://doi.org/10.1016/j.indmarman.2014.02.005

Gebauer, H., \& Fleisch, E. (2007). An investigation of the relationship between behavioral processes, motivation, investments in the service business and service revenue. Industrial Marketing Management, 36(3), 337-348. https://doi.org/10.1016/j.indmarman.2005.09.005

Gençtürk, E. F., \& Aulakh, P. S. (2007). Norms-and control-based governance of international manufacturer-distributor relational exchanges. Journal of International Marketing, 15(1), 92-126. https://doi.org/10.1509/jimk.15.1.092

Grönroos, C., \& Helle, P. (2010). Adopting a service logic in manufacturing: Conceptual foundation and metrics for mutual value creation. Journal of Service Management, 21(5), 564-590. https://doi.org/10.1108/09564231011079057

Grönroos, C., \& Voima, P. (2013). Critical service logic: Making sense of value creation and co-creation. Journal of the Academy of Marketing Science, 41(2), 133-150. https://doi.org/10.1007/s11747-012-0308-3

Hakanen, T., Helander, N., \& Valkokari, K. (2017). Servitization in global business-tobusiness distribution: The central activities of manufacturers. Industrial Marketing Management, 63, 167-178. https://doi.org/10.1016/j.indmarman.2016.10.011

Håkansson, H., \& Waluszewski, A. (2013). A never ending story - interaction patterns and economic development. Industrial Marketing Management, 42(3), 443-454. https://doi.org/10.1016/j.indmarman.2013.02.010

Håkansson, H., Snehota, I., Gadde, L. E., \& Ford, D. (2011). Managing business relationships. West Sussex: John Wiley \& Sons.

Harrison, J. S., \& Wicks, A. C. (2013). Stakeholder theory, value, and firm performance. Business Ethics Quarterly, 23(1), 97-124. https://doi.org/10.5840/beq20132314 
Harrison, J. S., Bosse, D. A., \& Phillips, R. A. (2010). Managing for stakeholders, stakeholder utility functions, and competitive advantage. Strategic Management Journal, 31(1), 58-74. https://doi.org/10.1002/smj.801

Herbig, P., \& O’Hara, B. S. (1994). Industrial distributors in the twenty-first century. Industrial Marketing Management, 23(3), 199-203. https://doi.org/10.1016/0019-8501(94)90033-7

Kastalli, I. V., \& Van Looy, B. (2013). Servitization: Disentangling the impact of service business model innovation on manufacturing firm performance. Journal of Operations Management, 31(4), 169-180. https://doi.org/10.1016/j.jom.2013.02.001

Kim, K. (2001). On the effects of customer conditions on distributor commitment and supplier commitment in industrial channels of distribution. Journal of Business Research, 51(2), 87-99. https://doi.org/10.1016/S0148-2963(99)00059-4

Kindström, D., Kowalkowski, C., \& Sandberg, E. (2013). Enabling service innovation: A dynamic capabilities approach. Journal of Business Research, 66(8), 1063-1073. https://doi.org/10.1016/j.jbusres.2012.03.003

King, B. G. (2008). A political mediation model of corporate response to social movement activism. Administrative Science Quarterly, 53(3), 395-421.

https://doi.org/10.2189/asqu.53.3.395

Kohtamäki, M., \& Partanen, J. (2016). Co-creating value from knowledge-intensive business services in manufacturing firms: The moderating role of relationship learning in suppliercustomer interactions. Journal of Business Research, 69(7), 2498-2506.

https://doi.org/10.1016/j.jbusres.2016.02.019

Kohtamäki, M., Partanen, J., \& Möller, K. (2013). Making a profit with R\&D services - the critical role of relational capital. Industrial Marketing Management, 42(1), 71-81. https://doi.org/10.1016/j.indmarman.2012.11.001

Kowalkowski, C., Kindström, D., \& Witell, L. (2011). Internalisation or externalisation? Examining organisational arrangements for industrial services. Managing Service Quality: An International Journal, 21(4), 373-391. https://doi.org/10.1108/09604521111146252

Kowalkowski, C., \& Ulaga, W. (2017). Service strategy in action: A practical guide for growing your B2B service and solution business. Amazon: Service Strategy Press.

Lenka, S., Parida, V., Rönnberg Sjödin, D., \& Wincent, J. (2018a). Exploring the microfoundations of servitization: How individual actions overcome organizational resistance. Journal of Business Research, 88, 328-336.

https://doi.org/10.1016/j.jbusres.2017.11.021

Lenka, S., Parida, V., Rönnberg Sjödin, D.,Wincent, J. (2018b). Towards a multi-level servitization framework: Conceptualizing ambivalence in manufacturing firms, International Journal of Operations \& Production Management, 38(3), 810827. https://doi.org/10.1108/IJOPM-09-2016-0542 
Li, Y., Cui, V., \& Liu, H. (2017). Dyadic specific investments, absorptive capacity, and manufacturers' market knowledge acquisition: Evidence from manufacturer-distributor dyads. Journal of Business Research, 78, 323-331.

https://doi.org/10.1016/j.jbusres.2016.12.028

Li, Y., Liu, Y., \& Liu, H. (2011). Co-opetition, distributors’ entrepreneurial orientation and manufacturers' knowledge acquisition: Evidence from China. Journal of Operations Management, 29(1), 128-142. https://doi.org/10.1016/j.jom.2010.07.006

Lusch, R. F., Vargo, S. L., \& Tanniru, M. (2010). Service, value networks and learning. Journal of the Academy of Marketing Science, 38(1), 19-31. https://doi.org/10.1007/s11747008-0131-z

Maignan, I., \& Ferrell, O. C. (2004). Corporate social responsibility and marketing: An integrative framework. Journal of the Academy of Marketing Science, 32(1), 3-19. https://doi.org/10.1177/0092070303258971

Mitchell, R. K., Agle, B. R., \& Wood, D. J. (1997). Toward a theory of stakeholder identification and salience: Defining the principle of who and what really counts. Academy of Management Review, 22(4), 853-886. https://doi.org/10.5465/amr.1997.9711022105

Mohr, J. J., Fisher, R. J., \& Nevin, J. R. (1996). Collaborative communication in interfirm relationships: moderating effects of integration and control. Journal of Marketing, 103-115. https://www.jstor.org/stable/1251844

Möller, K., \& Rajala, A. (2007). Rise of strategic nets - new modes of value creation. Industrial Marketing Management, 36(7), 895-908.

https://doi.org/10.1016/j.indmarman.2007.05.016

Müller-Seitz, G. (2012). Leadership in interorganizational networks: a literature review and suggestions for future research. International Journal of Management Reviews, 14(4), 428443. https://doi.org/10.1111/j.1468-2370.2011.00324.x

Narus, J. A., \& Anderson, J. C. (1987). Distributor contributions to partnerships with manufacturers. Business Horizons, 30(5), 34-42. https://doi.org/10.1016/00076813(87)90077-2

Nes, E. B., Solberg, C. A., \& Silkoset, R. (2007). The impact of national culture and communication on exporter-distributor relations and on export performance. International Business Review, 16(4), 405-424. https://doi.org/10.1016/j.ibusrev.2007.01.008

Ngugi, I. K., Johnsen, R. E., \& Erdélyi, P. (2010). Relational capabilities for value co-creation and innovation in SMEs. Journal of Small Business and Enterprise Development, 17(2), 260278. https://doi.org/10.1108/14626001011041256

Ocasio, W. (1997). Towards an attention-based view of the firm. Strategic Management Journal, 18, 187-206. https://doi.org/10.1002/(SICI)1097-0266(199707)18:1+<187::AIDSMJ936>3.0.CO;2-K 
Ocasio, W. (2011). Attention to attention. Organization Science, 22(5), 1286-1296. https://doi.org/10.1287/orsc.1100.0602

Oliva, R., \& Kallenberg, R. (2003). Managing the transition from products to services. International journal of Service Industry Management, 14(2), 160-172. https://doi.org/10.1108/09564230310474138

Olsson, R., Gadde, L. E., \& Hulthén, K. (2013). The changing role of middlemen - strategic responses to distribution dynamics. Industrial Marketing Management, 42(7), 1131-1140. https://doi.org/10.1016/j.indmarman.2013.06.006

Opresnik, D., \& Taisch, M. (2015). The value of Big Data in servitization. International Journal of Production Economics, 165, 174-184. https://doi.org/10.1016/j.ijpe.2014.12.036

Paiola, M., Saccani, N., Perona, M., \& Gebauer, H. (2013). Moving from products to solutions: Strategic approaches for developing capabilities. European Management Journal, 31(4), 390409. https://doi.org/10.1016/j.emj.2012.10.002

Parida, V., Rönnberg Sjödin, D., Wincent, J., \& Kohtamäki, M. (2014). A survey study of the transitioning towards high-value industrial product-services. Procedia CIRP, 16, 176-180. https://doi.org/10.1016/j.procir.2014.01.019

Parmar, B. L., Freeman, R. E., Harrison, J. S., Wicks, A. C., Purnell, L., \& De Colle, S. (2010). Stakeholder theory: The state of the art. Academy of Management Annals, 4(1), 403-445. https://doi.org/10.1080/19416520.2010.495581

Phillips, R., Freeman, R.E. \& Wicks, A.C. (2003). What stakeholder theory is not. Business Ethics Quarterly, 13(4), 479-502. https://doi.org/10.5840/beq200313434

Plaza-Úbeda, J. A., de Burgos-Jiménez, J., \& Carmona-Moreno, E. (2010). Measuring stakeholder integration: Knowledge, interaction and adaptational behavior dimensions. Journal of Business Ethics, 93(3), 419-442. https://doi.org/10.1007/s10551-009-0231-9

Poon, P. S., Evangelista, F. U., \& Albaum, G. (2005). A comparative study of the management styles of marketing managers in Australia and the People's Republic of China. International Marketing Review, 22(1), 34-47. https://doi.org/10.1108/02651330510581163

Prahalad, C. K., \& Ramaswamy, V. (2003). The new frontier of experience innovation. Sloan Management Review, 44(4), 12-18.

Quinn, J., \& Murray, J. A. (2005). The drivers of channel evolution: A wholesaling perspective. International Review of Retail, Distribution and Consumer Research, 15(1), 3-25. https://doi.org/10.1080/0959396042000299102

Revzan, D. A. (1961). Wholesaling in marketing organization. New York: Wiley. 
Rönnberg Sjödin, D., Parida, V., \& Wincent, J. (2016). Value co-creation process of integrated product-services: Effect of role ambiguities and relational coping strategies. Industrial Marketing Management, 56, 108-119. https://doi.org/10.1016/j.indmarman.2016.03.013

Rumelt, R. (1984). Towards a strategic theory of the firm. In R. Lamb (Ed.), Competitive Strategic Management (pp. 556-570). NJ: Prentice Hall.

Sandberg, J., \& Tsoukas, H. (2011). Grasping the logic of practice: Theorizing through practical rationality. Academy of Management Review, 36(2), 338-360.

https://doi.org/10.5465/amr.2009.0183

Shah, D., Rust, R. T., Parasuraman, A., Staelin, R., \& Day, G. S. (2006). The path to customer centricity. Journal of Service Research, 9(2), 113-124.

https://doi.org/10.1177/1094670506294666

Sirgy, M. J. (2002). Measuring corporate performance by building on the stakeholders model of business ethics. Journal of Business Ethics, 35(3), 143-162.

https://doi.org/10.1023/A:1013856421897

Stern, L., EI-Ansary, A. \& Coughlan, A. 1996. Marketing Channels. 5th ed. Englewood Cliffs, NJ: Prentice Hall.

Stieb, J. A. (2008). Assessing Freeman's stakeholder theory. Journal of Business Ethics, 87(3), 401-414. https://doi.org/10.1007/s10551-008-9928-4

Story, V. M., Raddats, C., Burton, J., Zolkiewski, J., \& Baines, T. (2017). Capabilities for advanced services: A multi-actor perspective. Industrial Marketing Management, 60, 54-68. https://doi.org/10.1016/j.indmarman.2016.04.015

Strauss, A., \& Corbin, J. (1994). Grounded theory methodology: An overview. In N. K. Denzin \& Y. S. Lincoln (Eds.), Handbook of qualitative research (pp. 273-285). Thousand Oaks, CA: Sage.

Tavory, I., \& Timmermans, S. (2014). Abductive analysis: Theorizing qualitative research. Chicago: University of Chicago Press.

Tuli, K. R., Kohli, A. K., \& Bharadwaj, S. G. (2007). Rethinking customer solutions: From product bundles to relational processes. Journal of Marketing, 71(3), 1-17.

https://doi.org/10.1509/jmkg.71.3.1

Ulaga, W., \& Loveland, J. M. (2014). Transitioning from product- to service-led growth in manufacturing firms: Emergent challenges in selecting and managing the industrial sales force. Industrial Marketing Management, 43(1), 113-125. https://doi.org/10.1016/j.indmarman.2013.08.006

Ulaga, W., \& Reinartz, W. J. (2011). Hybrid offerings: How manufacturing firms combine goods and services successfully. Journal of Marketing, 75(6), 5-23.

https://doi.org/10.1509/jm.09.0395 
Valtakoski, A. (2017). Explaining servitization failure and deservitization: A knowledge-based perspective. Industrial Marketing Management, 60, 138-150.

Visnjic, I., Wiengarten, F., \& Neely, A. (2016). Only the brave: Product innovation, service business model innovation, and their impact on performance. Journal of Product Innovation Management, 33(1), 36-52. https://doi.org/10.1016/j.indmarman.2016.04.009

Zhang, C., Cavusgil, S. T., \& Roath, A. S. (2003). Manufacturer governance of foreign distributor relationships: do relational norms enhance competitiveness in the export market?. Journal of International Business Studies, 34(6), 550-566.

https://doi.org/10.1057/palgrave.jibs.8400051

Weitz, B. A., \& Jap, S. D. (1995). Relationship marketing and distribution channels. Journal of the Academy of Marketing Science, 23(4), 305-320.

https://doi.org/10.1177/009207039502300411 
Tables and Figures

Table 1 Differences between IDs, manufacturers and manufacturer-owned dealers

\begin{tabular}{|c|c|c|c|}
\hline $\begin{array}{l}\text { Differentiating } \\
\text { factors }\end{array}$ & Independent distributors & Equipment manufacturers & Manufacturer-owned dealers \\
\hline $\begin{array}{l}\text { Role in the } \\
\text { ecosystem }\end{array}$ & $\begin{array}{l}\text { Provide services related to } \\
\text { sales, marketing, customer } \\
\text { relationships, logistics and offer } \\
\text { complementary services to the } \\
\text { wide range of machines \& } \\
\text { equipment they distribute on } \\
\text { the behalf of multiple } \\
\text { equipment manufacturers. } \\
\text { Serve a specific market } \\
\text { (product segment) where they } \\
\text { have an established customer } \\
\text { base and excellent knowledge } \\
\text { of the market (Olsson, 2013), } \\
\text { which offers less risky and } \\
\text { costly foreign market entry for } \\
\text { the equipment manufacturer } \\
\text { (Gençtürk \& Aulakh, 2007). }\end{array}$ & $\begin{array}{l}\text { Product design and } \\
\text { manufacturing along with } \\
\text { selling and installation of their } \\
\text { own machines or selling } \\
\text { through their own dealers } \\
\text { and/or independent distributors } \\
\text { accompanied with basic } \\
\text { services (Baines \& Lightfoot, } \\
\text { 2013). }\end{array}$ & $\begin{array}{l}\text { Provide services related to } \\
\text { sales, marketing, customer } \\
\text { relationships, logistics and } \\
\text { basic services on behalf of a } \\
\text { single equipment } \\
\text { manufacturer- carry a large } \\
\text { stock of products and spare } \\
\text { parts. } \\
\text { Ensure physical closeness to } \\
\text { manufacturer's principal } \\
\text { customer base with sales depots } \\
\text { and repair shops. } \\
\text { Expensive, but effective } \\
\text { channel for manufacturers to } \\
\text { leverage new business and } \\
\text { increase customers' switching } \\
\text { costs (Baines \& Lightfoot, } \\
\text { 2013). }\end{array}$ \\
\hline Product range & $\begin{array}{l}\text { Carry a range of hand-picked } \\
\text { product lines from a number of } \\
\text { equipment manufacturers } \\
\text { (Olsson, 2013). }\end{array}$ & $\begin{array}{l}\text { Develop and manufacture own } \\
\text { products (Ulaga \& Reinartz, } \\
\text { 2011). }\end{array}$ & $\begin{array}{l}\text { Carry product line(s) from a } \\
\text { single equipment manufacturer } \\
\text { (Baines \& Lightfoot, 2013). }\end{array}$ \\
\hline $\begin{array}{l}\text { Relationship with } \\
\text { customers }\end{array}$ & $\begin{array}{l}\text { Able to address the } \\
\text { heterogeneity of customers' } \\
\text { needs through assortment of } \\
\text { product lines they carry (Weitz } \\
\text { \& Jap, 1995). } \\
\\
\text { Perceived as less biased as they } \\
\text { do not favor products of a } \\
\text { single manufacturer, but rather } \\
\text { consider multiple options in } \\
\text { attempt to solve customer needs } \\
\text { (i.e., combine machines from } \\
\text { several manufacturers) (Fein \& } \\
\text { Anderson, 1997). }\end{array}$ & $\begin{array}{l}\text { Transactional relationship } \\
\text { influenced by the 'production } \\
\text { and consumption' business } \\
\text { model; responsibilities of the } \\
\text { ownership reside with the } \\
\text { customer (Baines \& Lightfoot, } \\
\text { 2013, p. 8). }\end{array}$ & $\begin{array}{l}\text { Proximity of maintenance } \\
\text { personnel and spare parts } \\
\text { enhance customers’ perception } \\
\text { of dealers reliability (Baines \& } \\
\text { Lightfoot, 2013). }\end{array}$ \\
\hline \multirow[t]{2}{*}{$\begin{array}{c}\text { Knowledge of } \\
\text { product }\end{array}$} & $\begin{array}{l}\text { Breath of knowledge, but } \\
\text { lacking depth due to large stock } \\
\text { of products from a wide range } \\
\text { of suppliers (Cespedes \& } \\
\text { Corey, 1990). }\end{array}$ & $\begin{array}{l}\text { Comprehensive product } \\
\text { knowledge and intellectual } \\
\text { property rights of products } \\
\text { they manufacture (Ulaga \& } \\
\text { Reinartz, 2011). }\end{array}$ & $\begin{array}{l}\text { In-depth knowledge of carried } \\
\text { product range from a single } \\
\text { manufacturer. }\end{array}$ \\
\hline & $\begin{array}{l}\text { Treat suppliers and business } \\
\text { customers as two separate } \\
\text { environmental entities (one in }\end{array}$ & $\begin{array}{l}\text { Collaborative communication } \\
\text { used to maintain positive } \\
\text { relationship with IDs (i.e. }\end{array}$ & $\begin{array}{l}\text { Fostering of shared values and } \\
\text { mutual support give dealer an } \\
\text { incentive to work on behalf of }\end{array}$ \\
\hline
\end{tabular}




\begin{tabular}{|c|c|c|c|}
\hline $\begin{array}{c}\text { Relationship with } \\
\text { other ecosystem } \\
\text { actors }\end{array}$ & $\begin{array}{l}\text { upstream channel, the other in } \\
\text { downstream channel) (Stern et } \\
\text { al., 1996). } \\
\text { Necessary to maintain a good } \\
\text { working relationship with } \\
\text { multiple suppliers (Gadde, } \\
\text { 2014). } \\
\text { Equipment manufacturer's } \\
\text { willingness to share exchange } \\
\text { risks and responsibilities is } \\
\text { reflected in investments made } \\
\text { towards building relationship } \\
\text { with ID (Zhang et al., 2003). }\end{array}$ & $\begin{array}{l}\text { development of operating } \\
\text { systems for ordering and } \\
\text { inventory control, provision of } \\
\text { training (Skarmeas et al., } \\
\text { 2008). } \\
\text { Manufacturer-owned dealers } \\
\text { as well as IDs help the } \\
\text { manufacturer in its } \\
\text { understanding of customers' } \\
\text { application and usage of their } \\
\text { product (Gençtürk \& Aulakh, } \\
\text { 2007). }\end{array}$ & $\begin{array}{l}\text { manufacturer's product (Mohr } \\
\text { et al., 1996). } \\
\text { Help financially invested } \\
\text { manufacturer to build a strong } \\
\text { relationship with business } \\
\text { customers at the operational } \\
\text { level (Baines \& Lightfoot, } \\
\text { 2013). }\end{array}$ \\
\hline $\begin{array}{l}\text { Challenges in } \\
\text { collaboration } \\
\text { with ecosystem } \\
\text { actors }\end{array}$ & $\begin{array}{l}\text { Physical separation between the } \\
\text { place of manufacture and } \\
\text { foreign market ID operates in is } \\
\text { often challenging and costly in } \\
\text { terms of interactions and } \\
\text { monitoring. } \\
\text { Different management styles } \\
\text { and practices between } \\
\text { international partners } \\
\text { complicate cross-border } \\
\text { dealings (Poon, Evangelista \& } \\
\text { Albaum, 2005). } \\
\text { Deal with the complexity of } \\
\text { serving a range of equipment } \\
\text { manufacturers and managing } \\
\text { their interests (Zhang et al., } \\
\text { 2003). }\end{array}$ & $\begin{array}{l}\text { Equipment manufacturers } \\
\text { commonly show a low level of } \\
\text { trust to IDs, criticising them } \\
\text { for lacking product knowledge } \\
\text { and favoring competitor's } \\
\text { product range (Cespedes \& } \\
\text { Corey, 1990). }\end{array}$ & $\begin{array}{l}\text { Success contingent on demand } \\
\text { for manufacturer's product on } \\
\text { the market and cannot offer } \\
\text { alternative products that are } \\
\text { from different equipment } \\
\text { manufacturers. } \\
\text { Often perceived by their } \\
\text { customers as biased as they sell } \\
\text { only products from a single } \\
\text { manufacturer (Mohr et al., } \\
\text { 1996). }\end{array}$ \\
\hline $\begin{array}{c}\text { Power } \\
\text { relationships } \\
\text { among ecosystem } \\
\text { actors }\end{array}$ & $\begin{array}{l}\text { Dependence on equipment } \\
\text { manufacturers is largest when a } \\
\text { few of them account for } \\
\text { majority of ID’s business or } \\
\text { only a few equipment } \\
\text { manufacturers want to supply } \\
\text { the market in which ID operates } \\
\text { (Zhang et al., 2003). }\end{array}$ & $\begin{array}{l}\text { Dependence is greatest when } \\
\text { the availability of competent } \\
\text { IDs in a foreign market is } \\
\text { limited and control of critical } \\
\text { resources is in the hands of IDs } \\
\text { (Kim, 2001). }\end{array}$ & $\begin{array}{l}\text { Manufacturers exercise their } \\
\text { power to gain dealers' full } \\
\text { cooperation through outright } \\
\text { ownership or } \\
\text { contractual/franchise } \\
\text { relationships (Mohr et al., } \\
\text { 1996). }\end{array}$ \\
\hline
\end{tabular}


Table 2 Informants and data-collection stages

\begin{tabular}{|c|c|c|c|c|c|c|c|c|c|}
\hline $\begin{array}{l}\text { Infor } \\
\text { mant } \\
\text { ID }\end{array}$ & $\begin{array}{l}\text { No. } \\
\text { of } \\
\text { interv } \\
\text { iews }\end{array}$ & $\begin{array}{l}\text { Informant's position } \\
\text { and association }\end{array}$ & $\begin{array}{l}\text { Exploratory } \\
\text { data } \\
\text { collection } \\
\text { stage } \\
\text { (mins) }\end{array}$ & $\begin{array}{l}\text { Focus } \\
\text { group } 1 \\
\text { (90 } \\
\text { minutes) }\end{array}$ & $\begin{array}{l}\text { Semi- } \\
\text { structured } \\
\text { interviews } \\
\text { (mins) }\end{array}$ & $\begin{array}{l}\text { Focus } \\
\text { group } 2 \\
(120 \\
\text { minutes })\end{array}$ & $\begin{array}{l}\text { Follow-up } \\
\text { interviews } \\
\text { (mins) }\end{array}$ & $\begin{array}{l}\text { Feedback } \\
\text { on } \\
\text { preliminary } \\
\text { findings } 1 \\
\text { (Group/90 } \\
\text { mins) }\end{array}$ & $\begin{array}{l}\text { Feedback } \\
\text { on } \\
\text { preliminary } \\
\text { findings } 2 \\
\text { (Group/90 } \\
\text { mins) }\end{array}$ \\
\hline I 1 & 4 & General Manager & 115 & $\mathrm{Y}$ & $60 ; 60$ & $\mathrm{Y}$ & 45 & $\mathrm{Y}$ & $\mathrm{Y}$ \\
\hline I 2 & 5 & Marketing Manager/HR & & & & & & & \\
\hline I 3 & 1 & $\begin{array}{l}\text { Manager } \\
\text { Marketing Assistant }\end{array}$ & $90 ; 120$ & $\mathrm{Y}$ & $60 ; 90$ & $\mathrm{Y}$ & 60 & $\mathrm{Y}$ & $\mathrm{Y}$ \\
\hline & & & & & 60 & $\mathrm{Y}$ & & & \\
\hline I 4 & 1 & $\begin{array}{l}\text { Ex National Sales } \\
\text { Manager }\end{array}$ & 90 & & & & & & \\
\hline I 5 & 2 & National Sales Manager & & & & & & & \\
\hline I 6 & 1 & Regional Sales Agent & & $\mathrm{Y}$ & 80 & $\mathrm{Y}$ & 30 & $\mathrm{Y}$ & $\mathrm{Y}$ \\
\hline I 7 & 3 & Engineering Manager & & & 40 & & & & $\mathrm{Y}$ \\
\hline & & & & $\mathrm{Y}$ & $90 ; 45$ & $\mathrm{Y}$ & 20 & & \\
\hline I 8 & 1 & Regional Engineer & & & 35 & & & & \\
\hline I 9 & 4 & Technical Manager & 60 & $\mathrm{Y}$ & $45 ; 60$ & & 30 & $\mathrm{Y}$ & \\
\hline I 10 & 2 & Service Manager & & $\mathrm{Y}$ & 60 & $\mathrm{Y}$ & 30 & $\mathrm{Y}$ & \\
\hline I 11 & 1 & $\begin{array}{l}\text { Production Manager } \\
\text { (ID's customer) } \\
\text { Medium-sized } \\
\text { Premium Bakery }\end{array}$ & & & 45 & & & & \\
\hline I 12 & 1 & $\begin{array}{l}\text { Business Owner (ID's } \\
\text { customer) Medium- } \\
\text { sized Cornish Pastry } \\
\text { Bakery }\end{array}$ & & & 40 & & & & \\
\hline I 13 & 2 & $\begin{array}{l}\text { Business Owner (ID's } \\
\text { customer) Small } \\
\text { family-owned Biltong } \\
\text { producer }\end{array}$ & & & $45 ; 60$ & & & & \\
\hline I 14 & 2 & $\begin{array}{l}\text { Sales Manager (ID’s } \\
\text { major equipment } \\
\text { supplier) Large } \\
\text { premium Italian } \\
\text { equipment } \\
\text { manufacturer }\end{array}$ & & & 45 & & 30 & & \\
\hline I15 & 2 & $\begin{array}{l}\text { Account Manager (ID’s } \\
\text { major equipment } \\
\text { supplier) Medium-sized } \\
\text { Swiss equipment } \\
\text { manufacturer }\end{array}$ & & & 45 & & 30 & & \\
\hline
\end{tabular}


Table 3 Overview of second-order themes, first-order categories, representative codes, and quotes

\begin{tabular}{|c|c|c|c|c|}
\hline $\begin{array}{c}\text { Second-order } \\
\text { theme }\end{array}$ & $\begin{array}{c}\text { First-order } \\
\text { category }\end{array}$ & $\begin{array}{c}\text { Representative } \\
\text { code }\end{array}$ & Representative quote & Informant \\
\hline \multirow{5}{*}{$\begin{array}{l}\text { Conflicting } \\
\text { interests of key } \\
\text { stakeholders }\end{array}$} & \multirow{3}{*}{$\begin{array}{l}\text { Misaligned goals } \\
\text { and incentives } \\
\text { between ID } \\
\text { and equipment } \\
\text { suppliers }\end{array}$} & \multirow{2}{*}{$\begin{array}{l}\text { Lacking } \\
\text { incentives for } \\
\text { ID's equipment } \\
\text { suppliers to } \\
\text { support its } \\
\text { transition }\end{array}$} & $\begin{array}{l}\text { "Like all the Italian suppliers, they want } \\
\text { you to sell lots [of packaging } \\
\text { machines]. They have this vision of the } \\
\text { UK market of being full of fantastic } \\
\text { opportunities. They tend not to } \\
\text { understand some of the other } \\
\text { difficulties with the market in the UK, } \\
\text { particularly with the competitors and } \\
\text { the growing need for services." }\end{array}$ & I9 \\
\hline & & & $\begin{array}{l}\text { "They are looking for lots of sales [key } \\
\text { partners]. Unless you are turning lots of } \\
\text { sales, you would be fairly low on the } \\
\text { list of their priorities. The problem is } \\
\text { that what they say and what they will } \\
\text { do is a bit different. When an engineer } \\
\text { needs a manual to go and fix a machine, } \\
\text { they haven't got one. When you go over } \\
\text { and do the customer demonstrations, } \\
\text { you fly over to Italy to do a customer } \\
\text { demonstration, but the machine does } \\
\text { not work and they have not done } \\
\text { anything about it." }\end{array}$ & I5 \\
\hline & & $\begin{array}{l}\text { High } \\
\text { dependency } \\
\text { on product- } \\
\text { dominant } \\
\text { suppliers }\end{array}$ & $\begin{array}{l}\text { "There are only few suppliers in the } \\
\text { market and we are sort of dependent on } \\
\text { them, but none of them has any } \\
\text { experience in providing or supporting } \\
\text { services to the industry. It is difficult to } \\
\text { find suppliers in our market who are } \\
\text { even partially supporting 'result-based' } \\
\text { services - leasing instead of selling, pay } \\
\text { per hour, and so on." }\end{array}$ & $\mathrm{I} 10$ \\
\hline & \multirow[b]{2}{*}{$\begin{array}{l}\text { Misaligned goals } \\
\text { and incentives } \\
\text { between ID } \\
\text { and customers }\end{array}$} & \multirow{2}{*}{$\begin{array}{l}\text { ID's offering } \\
\text { does not fully } \\
\text { respond to } \\
\text { customers' } \\
\text { requirements }\end{array}$} & $\begin{array}{l}\text { “The small start-ups are an opportunity } \\
\text { for us, but they are also a problem ... If } \\
\text { there is a start-up working in a 'kitchen } \\
\text { at home,’ why are we still trying to sell } \\
\text { them a } £ 100,000 \text { system?” }\end{array}$ & I5 \\
\hline & & & $\begin{array}{l}\text { "FoodPak provided us with free one- } \\
\text { hour training ... it was not enough to } \\
\text { learn how to operate the machine, it } \\
\text { was too much information for such a } \\
\text { short period of time, and the } \\
\text { instructions booklet that was supplied } \\
\text { with it was too technical - I couldn’t } \\
\text { understand it ... additional training was } \\
£ 1,000 \text { a day that should have been } \\
\text { included in the initial price.” }\end{array}$ & I13 \\
\hline
\end{tabular}




\begin{tabular}{|c|c|c|c|c|}
\hline & & $\begin{array}{l}\text { Undifferentiated } \\
\text { and generic } \\
\text { service } \\
\text { offerings }\end{array}$ & $\begin{array}{l}\text { "Within the food packaging market we } \\
\text { have three distinct groups of customers: } \\
\text { large multinationals, SMEs, and start- } \\
\text { ups. While they are interested in similar } \\
\text { product solutions, their service needs } \\
\text { differ largely. But we still try to sell } \\
\text { them the same service contracts." }\end{array}$ & I9 \\
\hline \multirow{6}{*}{$\begin{array}{l}\text { Misalignment } \\
\text { between } \\
\text { distribution of } \\
\text { managerial } \\
\text { attention and } \\
\text { servitization } \\
\text { strategy }\end{array}$} & \multirow{5}{*}{$\begin{array}{l}\text { Inconsistency in } \\
\text { vision } \\
\text { and execution }\end{array}$} & \multirow{3}{*}{$\begin{array}{l}\text { IDs current } \\
\text { activities and } \\
\text { processes do not } \\
\text { reflect its } \\
\text { strategic vision } \\
\text { for transition }\end{array}$} & $\begin{array}{l}\text { "It seems to me that the focus is on } \\
\text { making a quick sale and getting the } \\
\text { quotation to the customer as soon as } \\
\text { possible, instead of really nurturing that } \\
\text { relationship." }\end{array}$ & I6 \\
\hline & & & $\begin{array}{l}\text { "At the company the [main] focus is on } \\
\text { selling new machines. We have lots of } \\
\text { processes that are in some cases } \\
\text { outdated, not relevant to the size of our } \\
\text { company. It is not helping, but it keeps } \\
\text { people ticking the boxes." }\end{array}$ & I9 \\
\hline & & & $\begin{array}{l}\text { "We were looking for a flexible flow } \\
\text { wrapper that we could use to pack } \\
\text { different products in the future ... but } \\
\text { the salesperson was only interested in } \\
\text { making a quick sale." }\end{array}$ & I11 \\
\hline & & \multirow{2}{*}{$\begin{array}{l}\text { Struggle to } \\
\text { develop } \\
\text { transition } \\
\text { capabilities }\end{array}$} & $\begin{array}{l}\text { "The process should be standardized, } \\
\text { but there are still many employees who } \\
\text { do not work towards the same process } \\
\text {. . well, certainly I feel that the } \\
\text { packaging was a bit of an island inside } \\
\text { FoodPak - with everyone doing their } \\
\text { own thing, really." }\end{array}$ & I7 \\
\hline & & & $\begin{array}{l}\text { "All my proposals that could facilitate } \\
\text { transition were overruled by the } \\
\text { Financial Manager for budget } \\
\text { reasons. . . . The Financial Department } \\
\text { seems to be running the company; we } \\
\text { focus on projects that can deliver } \\
\text { immediate results and rarely seek } \\
\text { customer feedback after the sale." }\end{array}$ & $\mathrm{I} 2$ \\
\hline & Departmentalism & $\begin{array}{l}\text { Goals and } \\
\text { incentives are } \\
\text { not consistent } \\
\text { among ID's } \\
\text { functions }\end{array}$ & $\begin{array}{l}\text { “One of the issues we had with } \\
\text { incentives schemes was difficulty } \\
\text { coming up with one that sort of fits } \\
\text { everybody ... Some engineers } \\
\text { wouldn’t engage in that at all ... My } \\
\text { job is to fix machines, not to sell } \\
\text { machines.” }\end{array}$ & I1 \\
\hline
\end{tabular}




\begin{tabular}{|c|c|c|c|c|}
\hline & & & $\begin{array}{l}\text { "Sometimes when salespeople are } \\
\text { under pressure to sell, that can get } \\
\text { viewed as ... I'm trying to make it } \\
\text { happen, don't put obstacles in my way } \\
\text { - you're there to take obstacles out of } \\
\text { my way [referring to salespeople's view } \\
\text { of the technical function].” }\end{array}$ & I1 \\
\hline & & $\begin{array}{l}\text { Competition } \\
\text { instead of } \\
\text { collaboration } \\
\text { among different } \\
\text { functions }\end{array}$ & $\begin{array}{l}\text { "There seems to be a disconnect } \\
\text { between the technical projects team, } \\
\text { sales, and the service team ... they } \\
\text { blame each other for problems instead } \\
\text { of working together on fixing them." }\end{array}$ & I1 \\
\hline \multirow{4}{*}{$\begin{array}{l}\text { Ineffective } \\
\text { knowledge } \\
\text { management } \\
\text { within the } \\
\text { ecosystem }\end{array}$} & \multirow{4}{*}{$\begin{array}{l}\text { Ecosystem } \\
\text { knowledge } \\
\text { lost } \\
\text { internally }\end{array}$} & \multirow{2}{*}{$\begin{array}{l}\text { Knowledge } \\
\text { silos within } \\
\text { different } \\
\text { functions }\end{array}$} & $\begin{array}{l}\text { "The salespeople don’t use CRM ... } \\
\text { they could not only record product } \\
\text { quotes within that system, but also } \\
\text { append more non-technical information } \\
\text { to the customer name. All of that } \\
\text { knowledge could be held [and shared] } \\
\text { within that system ... this is how you } \\
\text { start losing all those 'nuggets,' so we } \\
\text { acknowledge it is not very joined up at } \\
\text { the moment.” }\end{array}$ & I1 \\
\hline & & & $\begin{array}{l}\text { "All the time when you have silos of } \\
\text { knowledge and info dotted around the } \\
\text { company, you'll never be able to } \\
\text { provide that service. ... We'd have that } \\
\text { info and make a note in three months' } \\
\text { time and see how they are getting on. } \\
\text { We're totally failing in sharing that } \\
\text { info.” }\end{array}$ & I2 \\
\hline & & \multirow{2}{*}{$\begin{array}{l}\text { No codification } \\
\text { of holistic } \\
\text { customer and } \\
\text { production } \\
\text { equipment } \\
\text { information } \\
\text { (lack of } \\
\text { processes) }\end{array}$} & $\begin{array}{l}\text { "It's so critical that customer } \\
\text { information is shared and not kept in } \\
\text { the salesman's head, because if that } \\
\text { salesmen leaves us ... that's something } \\
\text { that happened to us; we had a couple } \\
\text { who moved on and they took that } \\
\text { information with them. Knowledge is } \\
\text { gone with the sales representative. They } \\
\text { don't deliver any formal reports to the } \\
\text { head office.” }\end{array}$ & I4 \\
\hline & & & $\begin{array}{l}\text { "The sales team finds it [CRM] quite } \\
\text { difficult to use, so there's a tendency } \\
\text { for them not to use it. It's a fairly old } \\
\text { piece of kit and we tend to use it more } \\
\text { as a transactional filing cabinet.” }\end{array}$ & I2 \\
\hline
\end{tabular}




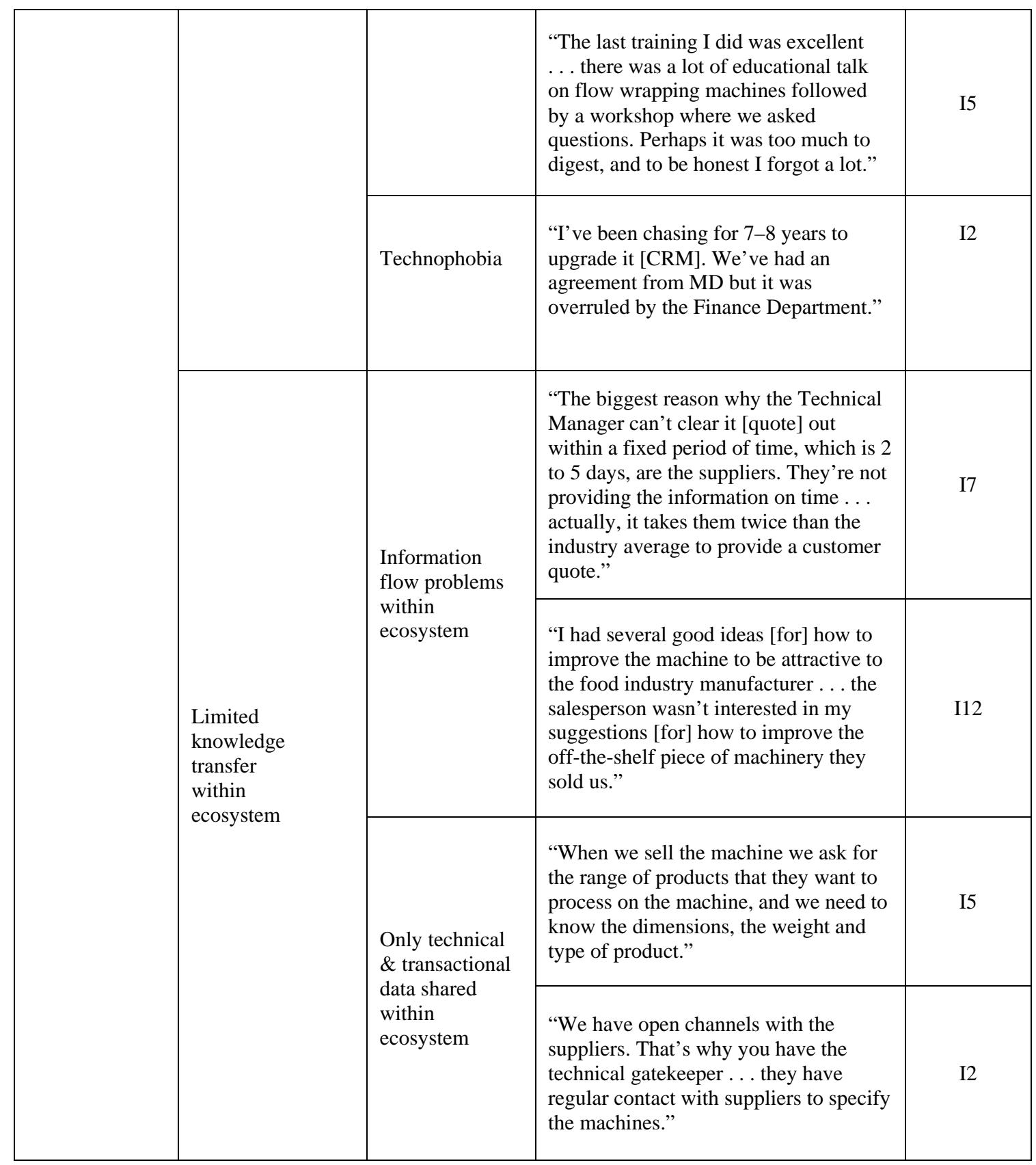


Figure 1 Coding Scheme

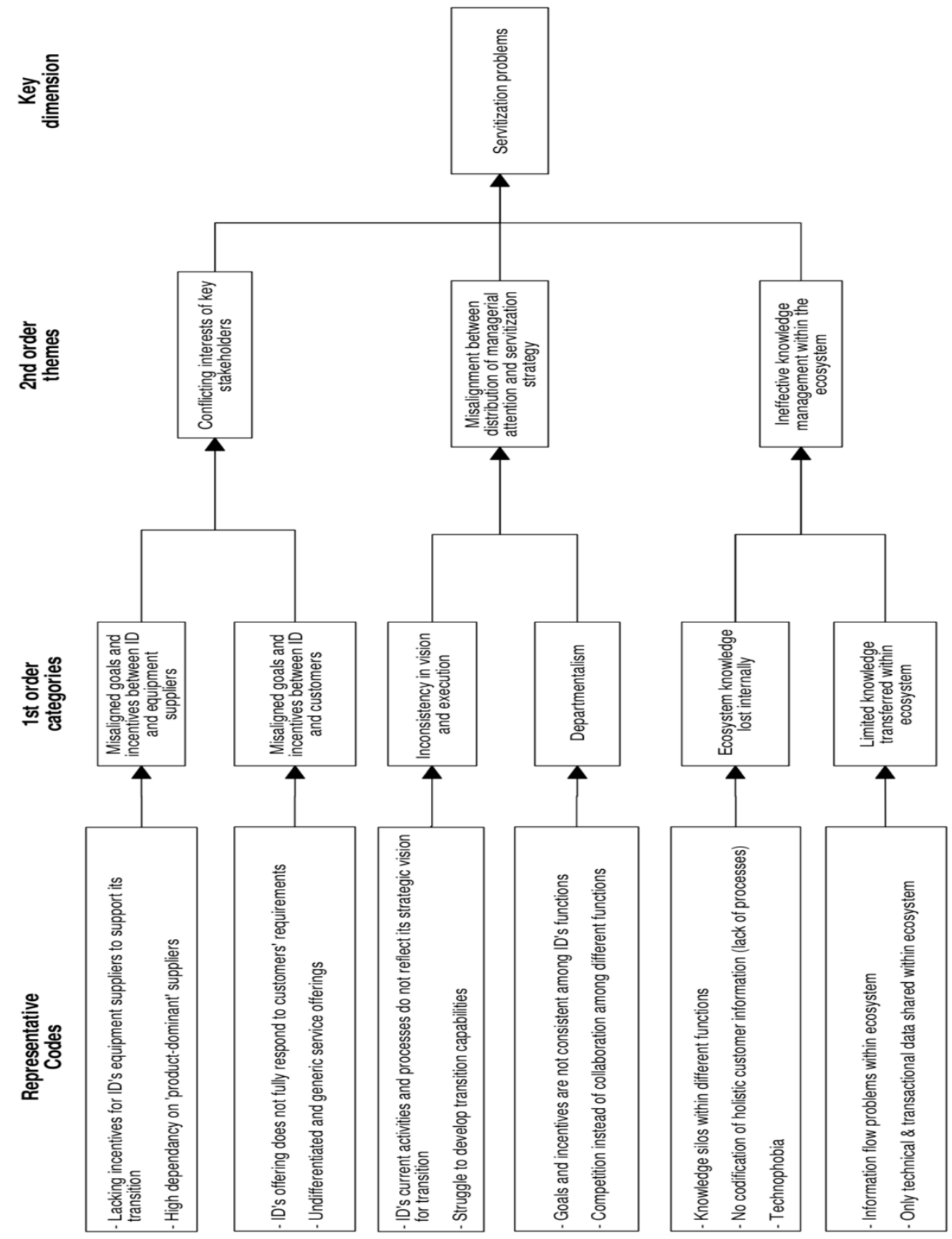


Figure 2 Servitization readiness decision tree

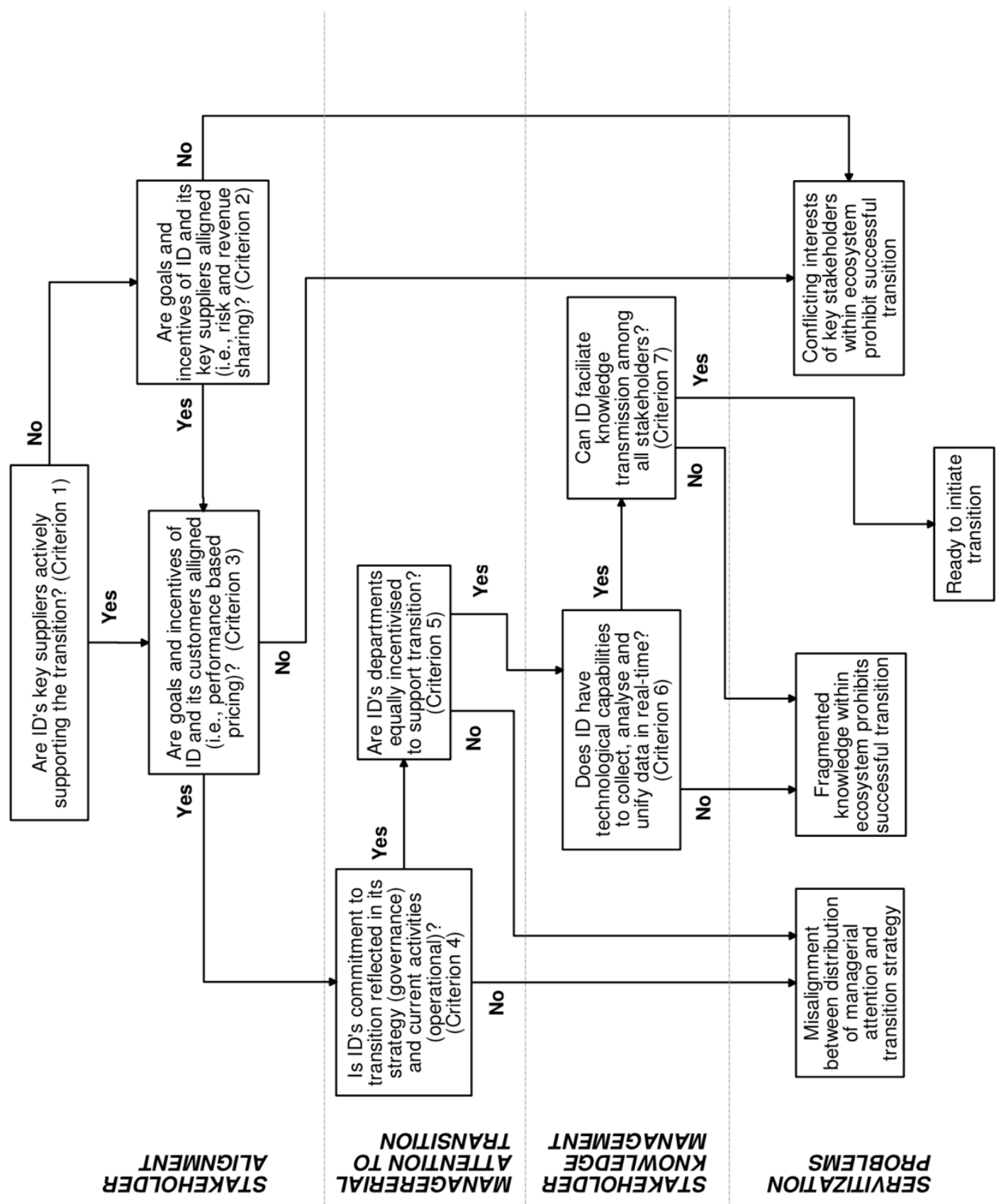

